\title{
NEW AND NOTEWORTHY LICHEN-FORMING AND LICHENICOLOUS FUNGI $3^{*}$
}

\author{
S. Y. KONDRATYUK ${ }^{1}$, L. LóKÖs ${ }^{2}$, E. FARKAS ${ }^{3}$, S.-O. OH ${ }^{4}$ and J.-S. HuR ${ }^{4}$ \\ ${ }^{1}$ M. H. Kholodny Institute of Botany, Tereshchenkivska str. 2, 01004 Kiev, Ukraine \\ E-mail:ksya_net@ukr.net \\ ${ }^{2}$ Department of Botany, Hungarian Natural History Museum \\ H-1476 Budapest, Pf. 222, Hungary; E-mail: lokos@bot.nhmus.hu \\ ${ }^{3}$ Institute of Ecology and Botany, Centre for Ecological Research, Hungarian Academy of Sciences \\ H-2163 Vácrátót, Alkotmány u. 2-4, Hungary \\ ${ }^{4}$ Korean Lichen Research Institute, Sunchon National University, Sunchon 540-742, Korea \\ E-mail: jshur1@sunchon.ac.kr
}

(Received 14 July, 2015; Accepted 30 August, 2015)

\begin{abstract}
Eleven new for science species of lichen-forming fungi, i.e.: Amandinea pseudomultispora, Buellia chujadoensis, Fuscidea coreana, F. extremorientalis, Hafellia extremorientalis, H. pseudosubnexa, Halecania subalpivaga, Lecanactis subdilleniana, Lecania chirisanensis, Maronella corea$n a$, and Melanophloea coreana are described, illustrated and compared with closely related taxa. Amandinea polyspora, Catillaria nigroclavata, Ivanpisutia oxneri, Lecanora saligna, L. sambuci, and Lecidella mandshurica are proved to be new to Korea.
\end{abstract}

Key words: Amandinea, Buellia, Fuscidea, Hafellia, Halecania, Korea, Lecanactis, Lecania, Maronella, Melanophloea, new for science

\section{INTRODUCTION}

Our knowledge on the biodiversity of lichen-forming and lichenicolous fungi of the Korean Peninsula has increased considerably in the last decade. More than 1,100 taxa have been published up to now. This estimation is based on mainly three lichen checklists: Ri (1988) with 317 taxa, Hur et al. (2005) with 516 taxa and Moon (2013) with 788 taxa. In addition, some more recent publications were considered (e.g. Aptroot and Moon 2014, 2015, Kondratyuk et al. 2013, 2015) updated also by some older but overlooked sources (e.g. Arvidsson 1982, Degelius 1974, Szerdahelyi and Lőkös 1992, Vězda 1988).

Among these 1,100 taxa about 120 species were described as new for science from territory of South Korea (i.e. about 10\% of total number of species). Approximately, about half of them were described during the last 10 years (2005-2015). The number of species of lichenicolous fungi is hitherto around 20.

\footnotetext{
* Previous contributions were published in 2013 and 2015 (Kondratyuk et al. 2013, 2015).
} 
As a continuation of our former papers (Kondratyuk et al. 2013, 2015) in this paper we intend to add 11 new species of lichen-forming fungi and some more occurrence records to the Korean lichen flora.

\section{MATERIALS AND METHODS}

A total of 1,300 specimens were sampled during the current collections in 2014, and these are deposited in the Korean Lichen Research Institute, Sunchon National University, South Korea (hereafter KoLRI), as well as some duplicates in the Hungarian Natural History Museum (hereafter BP) and the Lichen Herbarium of M. H. Kholodny Institute of Botany of the National Academy of Sciences of Ukraine (hereafter KW-L).

The specimens were examined using standard microscopical techniques and hand-sectioned under a dissecting microscope (Nikon SMZ 645; Nikon, Tokyo, Japan). Anatomical descriptions were based on observations of these preparations under a microscope (Nikon Eclipse E200; Nikon, Tokyo, Japan, and Zeiss Scope. A1; Carl Zeiss, Oberkochen, Deutschland, Germany) with digital camera AxioCam ERc 5s. Section of apothecia were tested with water and with $\mathrm{K}$ and IKI (10\% aqueous potassium iodide) for identification.

\section{RESULTS AND DISCUSSION}

Amandinea pseudomultispora S. Y. Kondr., L. Lőkös et J.-S. Hur, spec. nova (Fig. 1)

Mycobank no.: MB 814516.

Similar to Amandinea multispora, but differs in having darker thallus, in having bigger apothecia, in having thicker exciple evenly coloured throughout, in having reddish brown epihymenium, in the lack of cups at tips of paraphyses, in having thinner subhymenium, in having wider range of number of ascospores in ascus (24-)32-48(-64), in having larger ascospores.

Type: South Korea: Gangwon-do province, Sokcho-si, Mt Seorak, on bark, growing together with Lecidella mandshurica (new to Korea). Lat.: $38^{\circ} 09^{\prime}$ 58.86" N; Long.: $128^{\circ} 27^{\prime} 16.02^{\prime \prime}$ E; Alt.: ca 463 m a.s.l. Coll.: Joshi, Y., Wang, X. Y., Ryu, J. A. (090797), 24.05.2009 (holotype: KoLRI 010469).

Thallus crustose, areolate, upper surface continuous, thin and slightly cracked to rather thick in the centre, where areoles to $0.5-1.5 \mathrm{~mm}$ across with tendency to be exfoliating often observed, dark grey or greenish grey, smooth, 
epruinose, with numerous black apothecia. Prothallus distinct or mainly absent, seen as black line to $0.5 \mathrm{~mm}$ wide around.

Apothecia 0.3-1(-1.3) $\mathrm{mm}$ in diam., (in section to $0.13-0.3 \mathrm{~mm}$ thick), lecideine, initially immersed soon becoming adnate to sessile, usually regularly rounded or at overmature with waving margins; margin prominent, usually persistent, to $0.1 \mathrm{~mm}$ wide, rarely excluded with age, black to somewhat brownish black or greyish/hyaline/transparent black and shining; disc black, epruinose, plane or slightly subconvex; in section true exciple to (50-)60-120 $\mu \mathrm{m}$ thick in the uppermost lateral portion, to $60-120(-140) \mu \mathrm{m}$ thick in lower lateral and basal portions, dark brown, or dark olive brown to blackish brown, $\mathrm{K}+$ bright orange-red, dissolving into solution, then turning to deep yellow-orange, containing reddish orange crystals to $12 \mu \mathrm{m}$ long and $1 \mu \mathrm{m}$ diam.; hymenium 90-120 $\mu \mathrm{m}$ high, hyaline, not inspersed with oil droplets; epihymenium 7.5-10 $\mu \mathrm{m}$ thick, brownish to dark brown, somewhat reddish brown, in $\mathrm{K}$ becoming dull olive brown; paraphyses about $1.5 \mu \mathrm{m}$ diam., apically slightly swollen, to $2.5-3 \mu \mathrm{m}$ diam.; subhymenium (15-)20-30 $\mu \mathrm{m}$ thick, pale olivaceous, greyish or olive brown, dark brown to blackish; asci (24-)32-48(-64?)-spored, 75-90 × 22-30 $\mu \mathrm{m}$; ascospores 1-septate, narrowly ellipsoid, cell wall uniformly thick, surface smooth, brown to dark brown, $(8-) 9-13(-15) \times(5-) 5.5-8 \mu \mathrm{m}$. Pycnidia and conidia unknown.

Chemistry: Thallus $\mathrm{K}+$ yellow then turning orange or red, $\mathrm{C}-, \mathrm{KC}-, \mathrm{P}-$.

Ecology: It grows on bark of various broad leaved trees.

Etymology: It is named after its similarity with Amandinea multispora.

Distiribution: So far known from scattered localities of South Korea, Eastern Asia.

Taxonomic notes: Amandinea pseudomultispora is similar to A. multispora (Kalb et Vězda) Marbach (Marbach 2000), known from Hawaii, Brazil, Puerto Rico, Venezuela and the Philippines, but differs in having darker thallus ( $v$. whitish, $\mathrm{K}-$ ), in having bigger apothecia (0.3-0.9 $\mathrm{mm} v$. to $0.4 \mathrm{~mm}$ diam.), in having thicker exciple evenly coloured throughout $(v$. differentiated coloration, outer dark and hyaline inner portions), in having reddish brown epihymenium, in the lack of cups at tips, in having thinner subhymenium (20-30 $\mu \mathrm{m} v .70-80 \mu \mathrm{m}$ thick), in having wider range of number of ascospores in ascus ((24-)32-48(-64) v. 30-50 per ascus), in having larger ascospores ((8-)9$13(-15) \times(5-) 5.5-8 \mu \mathrm{m} v .7-9 \times 3-4.5 \mu \mathrm{m})$.

From Amandinea polyspora (Willey) E. Lay et P. F. May in Sheard and May (1997) Amandinea pseudomultispora differs in having thallus $\mathrm{K}+$ yellow (v. thallus grey, $\mathrm{K}-)$, in having (24-)32-48-spored asci (v. 12-32-spored), also in having wider ascospores $((8-) 9-13(-15) \times(5-) 5.5-8 \mu \mathrm{m} v \cdot(7.4) 9-10(-11.7) \times(3.5-)$ 4.4-4.5(-5.4) $\mathrm{mm}$ ) (Giralt et al. 2002, Marbach 2000, Sheard and May 1997). 

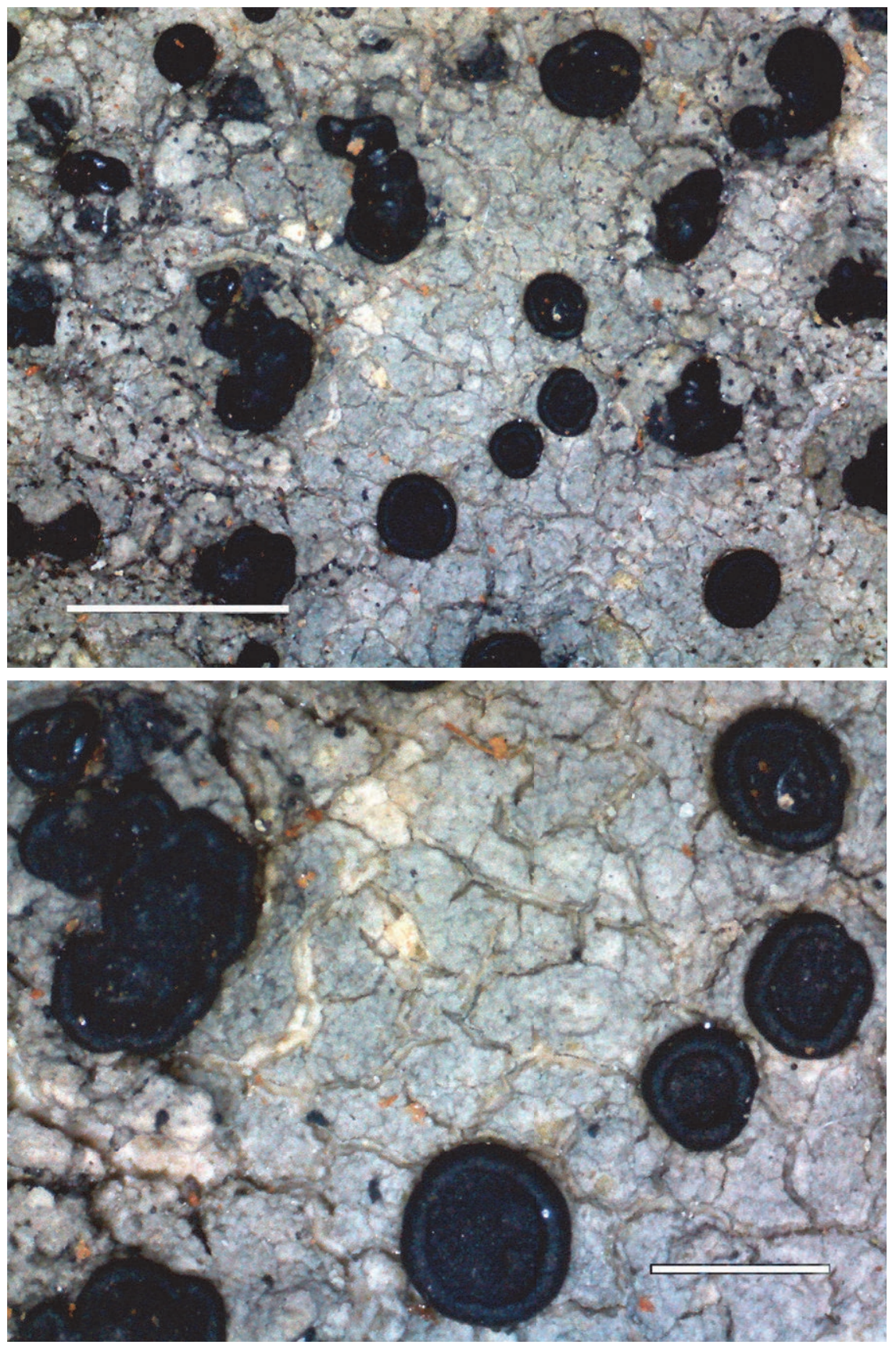

Fig. 1. Amandinea pseudomultispora, general habit (holotype). Scale $2 \mathrm{~mm}$ (top) and $1 \mathrm{~mm}$ (bottom) (photo: S. Kondratyuk) 
Amandinea pseudomultispora is similar to Hafellia pseudosubnexa S. Y. Kondr., L. Lőkös et J.-S. Hur, described below, but differs in having not dispersed hymenium, in having larger number of ascospores in ascus and smaller measurements of ascospores. However it should be mentioned that macroscopically sometimes (see KoLRI 010072 and KoLRI 010537) it is hard to recognise Amandinea pseudomultispora among thalli of Hafellia pseudosubnexa and their identification will be possible only after studying the apothecium section.

Amandinea pseudomultispora is similar to Lecidella mandshurica S. Y. Kondr., L. Lökös et J.-S. Hur, with which it often growing side by side, but differs in having black or somewhat brownish black or hyaline/transparent black own margin of lecideine apothecia in having thicker apothecia, in having polyspored asci and in having dark 1-septate ascospores and in the lack of golden colour of own margin, giving K+ ink-violet colouration (see also Kondratyuk et al. 2015).

Additional specimens examined: South Korea. Jeju-do province: Mt Halla (Gwanumsa Trail). Lat.: $33^{\circ} 22^{\prime}$ 09.01" N; Long.: $126^{\circ} 31^{\prime}$ 53.03" E; Alt.: ca 1,570 m a.s.l., on tree, growing together with Pertusaria subcomposita. Coll.: Oh, S.-O., Jayalal, U., Joshi, S., Park, J. S., Tian, F. H., Hur, J.-S. (121115) 19.06.2012 (KoLRI 016151). - Gangwon-do province: Samcheok-si, Hajang-myeon, Mt Sambong, on bark of tree, growing together with Biatora sp., Catillaria nigroclavata (new to Korea), Hafellia pseudosubnexa, Lecanora aff sambuci (new to Korea), Rinodina sp. and Scoliciosporum chlorococcum. Lat.: $37^{\circ} 18^{\prime} 18.36^{\prime \prime}$ N; Long.: $128^{\circ}$ 56' 22.08" E; Alt.: ca 930 m a.s.l. Coll.: Joshi, Y., Wang, X. Y., Ryu, J. A., Hur, J. Y. (090344) 15.05.2009 (KoLRI 010072 sub Hafellia pseudosubnexa); Sokcho-si, Mt Seorak, on bark, growing together with Hafellia pseudosubnexa. Lat.: $38^{\circ} 09^{\prime} 57.96^{\prime \prime} \mathrm{N}$; Long.: $128^{\circ} 27^{\prime} 44.70^{\prime \prime}$ E; Alt.: ca 745 m a.s.l. Coll.: Joshi, Y., Wang, X. Y., Ryu, J. A. (090865) 24.05.2009 (KoLRI 010537, sub Hafellia pseudosubnexa). - Jeollanam-do province: Chiri Mts, on Acer bark. Lat.: $35^{\circ} 20^{\prime} 00.5^{\prime \prime}$ N; Long.: $127^{\circ} 43^{\prime}$ 02.1" E; Alt.: ca 1,645 (=1,555) m a.s.l. Coll.: Hur, J.-S. (060705) 16.09.2006 (KoLRI 005083).

Specimen of Amandinea polyspora examined: South Korea. Jeollanam-do province: Yeosu-si, Odong-do Island, along the tourist path, on bark of trees (Camellia japonica, Machilus thunbergii, Quercus serrata), growing together with Micarea sp. Lat.: $34^{\circ} 44^{\prime} 37.75^{\prime \prime} \mathrm{N}$; Long.: $127^{\circ} 45^{\prime}$ 50.57" E; Alt.: ca 25 m a.s.l. Coll.: Kondratyuk, S. Y., Lőkös, L., Park, C. H. (130732) 28.07.2013 (KoLRI 019374). - New to Korea.

Buellia chujadoensis L. Lőkös, S. Y. Kondr. et J.-S. Hur, spec. nova (Fig. 2)

Mycobank no.: MB 814517.

Similar to Buellia halonia, but differs in having thinner thallus, in having smaller apothecia, in having smaller ascospores, as well as in the lack of K+ pigments in medulla.

Type: South Korea: Jeju-do province, Jeju-si, Chuja-do Island, Chuja-myeon, Yecho-ri, Mt Dondae, on rock, growing together with Buellia stellulata, and Lecanora sp. Lat.: 33 56' 53.9" N; Long.: 126 19' 26.7" E; Alt.: ca $164 \mathrm{~m}$ 
a.s.1. Coll.: Kondratyuk, S. Y. (SK-06-1a), (140815), 20.06.2014 (holotype: KoLRI $023300 \mathrm{sub}$ Buellia stellulata); the same locality, growing together with Buellia stellulata (140802-1), (isotype: KoLRI 023282 sub Buellia stellulata); the same locality, growing together with Buellia stellulata and Lecanora lojkahugoi, (1408022), (isotype: KoLRI 023283 sub Buellia stellulata); the same locality, growing together with Buellia stellulata and Lecanora lojkahugoi, (140812), (isotype: KoLRI 023297 sub Buellia stellulata).

Thallus crustose, areolate, prothallus usually distinct seen as black line around, upper surface yellowish green to pale yellow, smooth, epruinose; in section thallus to 90-100 $\mu \mathrm{m}$ thick, cortical layer to $20 \mu \mathrm{m}$ thick, with epinecral layer to $10 \mu \mathrm{m}$ thick in places; algal layer to $50 \mu \mathrm{m}$ thick, medulla white (without rust-red, $\mathrm{K}+$ purplish pigment).

Apothecia lecideine, $0.1-0.25(-0.3) \mathrm{mm}$ in diam., (in section to $0.8 \mathrm{~mm}$ thick), initially immersed soon becoming adnate to sessile, margin black prominent, usually persistent, rarely excluded with age; disc black, epruinose; in section true exciple to 20-30 $\mu \mathrm{m}$ thick in the uppermost lateral portion with brownish to blackish outer layer to $10 \mu \mathrm{m}$ thick, 15-30 $\mu \mathrm{m}$ thick in lower lateral portion, hyaline; hymenium 50-60 $\mu \mathrm{m}$ high, hyaline, not inspersed with oil droplets; epihymenium blackish brown; paraphyses apically swollen, with a brown pigment cap to 3-4.5(-6) $\mu \mathrm{m}$ diam.; subhymenium 10-20 $\mu \mathrm{m}$ thick, hyaline; asci 8 -spored; ascospores 1-septate, widely ellipsoid, greyish brown af first, than brown to dark brown, (9-)10-13(-14) $\times 5-7 \mu \mathrm{m}$.

Pycnidia and conidia unknown.

Chemistry: $\mathrm{K}+$ yellow or weakly yellow, $\mathrm{C}+$ deep yellow to orange, $\mathrm{KC}+$ deep yellow to orange, $\mathrm{P}+$ yellow, reaction somewhat slow.

Ecology: It grows on siliceous rocks in supralittoral zone often growing together with various species of the genera Buellia, Caloplaca and Lecanora.

Etymology: It is named after type collection in Chuja-do Island, South Korea.

Distiribution: So far known from scattered localities of South Korea, Eastern Asia.

Taxonomic notes: Similarly to Buellia halonia (Ach.) Tuck., epilithic lichen growing on siliceous mineral-poor coastal rock, and rather common in Western North America, Buellia chujadoensis can be easily recognised by its yellowish green, C+ orange, areolate thallus. However Buellia chujadoensis differs from the latter in having thinner thallus, in having smaller apothecia $(0.1-0.25(-0.3) \mathrm{mm} v \cdot 0.3-0.5(-0.7) \mathrm{mm}$ in diam.), in having smaller ascospores $((9-) 10-13(-14) \times 5-7 \mu \mathrm{m} v \cdot(11.5-) 12.5-16(-19) \times 7-8(-9) \mu \mathrm{m})$, as well as in the lack of $\mathrm{K}+$ pigments in medulla.

Additional specimens examined: South Korea. Jeju-do province: Jeju-si, Cheju-do Island, Hangyeong-eup, Sinchang-ri, seashore road, on rock, growing together with Buellia 

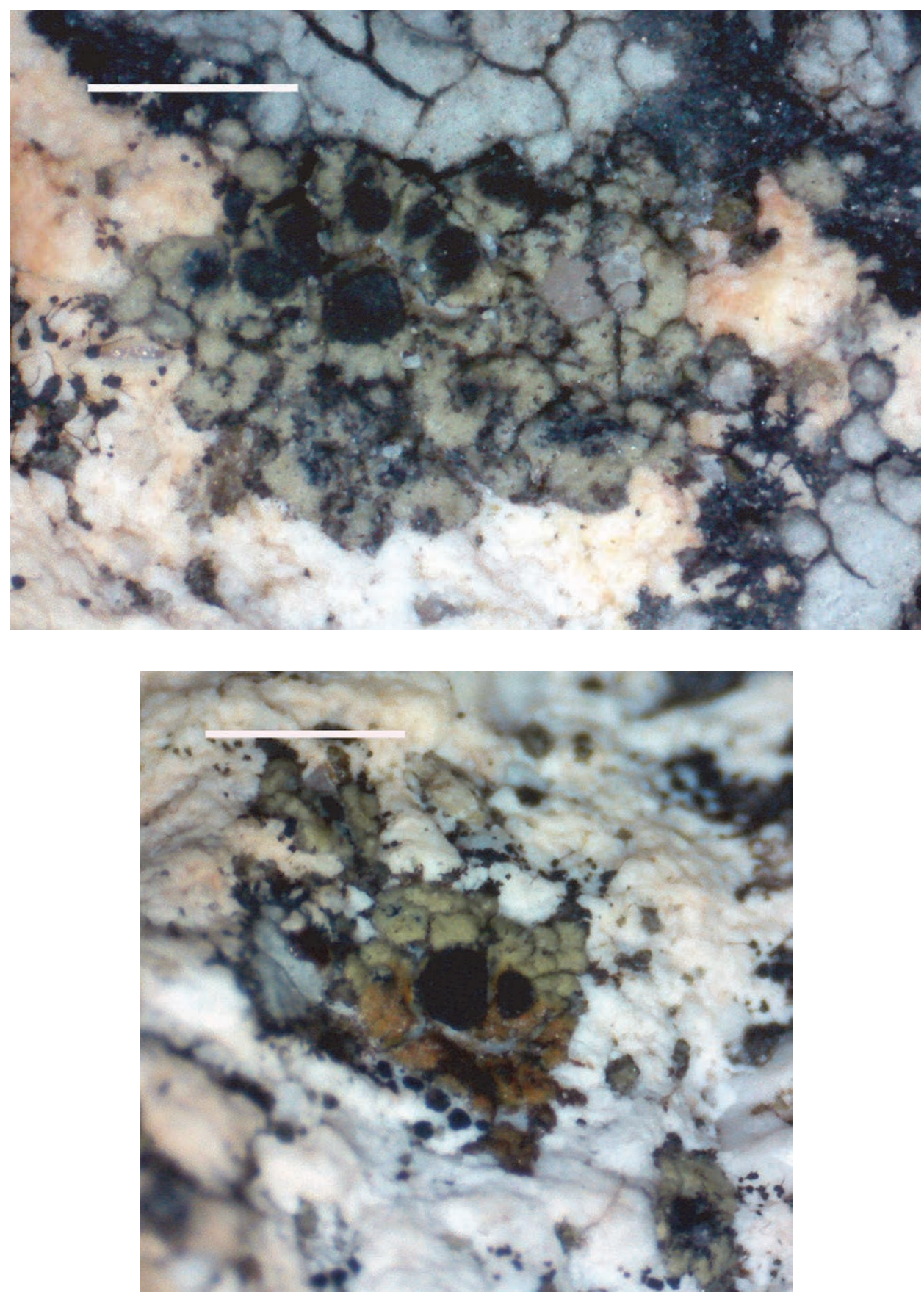

Fig. 2. Buellia chujadoensis, general habit (holotype). Scale $1 \mathrm{~mm}$ (photo: S. Kondratyuk) 
stellulata. Lat.: $33^{\circ} 20^{\prime} 31.6^{\prime \prime} \mathrm{N}$; Long.: 126 10' 12.08” E; Alt.: ca $82 \mathrm{~m}$ a.s.l. Coll.: Lőkös, L. (140201), 18.06.2014 (KoLRI 022571 sub Buellia stellulata); the same locality. Coll.: Lőkös, L. (140207-2) 18.06.2014 (KoLRI 022580); the same locality, growing together with Caloplaca subconcilians and Pertusaria sp. Coll.: Kondratyuk, S. Y. (SK-01), (140257), 18.06.2014 (KoLRI $022613 \mathrm{sub}$ Caloplaca subconcilians); the same locality, growing together with Buellia sp. Coll.: Joshi, Y., So, J. E. (140768), 18.06.2014 (KoLRI 023242 sub Buellia); the same locality, growing together with Lecanora lojkahugoi and Buellia sp. Coll.: Gagarina, L. (140787), 18.06.2014 (KoLRI 023263 sub Buellia); the same locality, growing together with Buellia sp. and Lichenothelia sp. Coll.: Kondratyuk, S. Y. (140792-1), 18.06.2014 (KoLRI 023271 sub Buellia); the same locality, growing together with Lecanora sp. Coll.: Kondratyuk, S. Y. (140808), 18.06.2014 (KoLRI 023292 sub Lecanora); Seogwipo-si, Cheju-do Island, Seongsan-eup, Goseong-ri, Seopjicoji. Lat.: 33 19’21.0" N; Long.: 126 50’ 49.03" E; Alt.: ca 69 m a.s.l., on rock, growing together with Buellia stellulata. Coll.: Joshi, Y. (140474) 19.06.2014 (KoLRI 022875 sub Buellia stellulata); Jeju-si, Chuja-do Island, Chuja-myeon, Yecho-ri, Mt Dondae, on rock, growing together with Fuscidea coreana and Lecanora lojkahugoi. Lat.: $33^{\circ} 56^{\prime} 53.9^{\prime \prime}$ N; Long.: 126 19' 26.7" E; Alt.: ca 164 m a.s.l. Coll.: Halda, J. P. (140821), 20.06.2014 (KoLRI 023306 sub Buellia); Jeju-si, Chuja-do Island, Chuja-myeon, Sinyang-1-ri, seashore of Mojini-mongdol, on rock, growing together with Buellia stellulata and Lecanora sp. Lat.: $33^{\circ} 56^{\prime} 44.9^{\prime \prime}$ N; Long.: $126^{\circ} 20^{\prime}$ 03.01" E; Alt.: ca 57 m a.s.l. Coll.: Kondratyuk, S. Y. (SK-07), (140884-3), 21.06.2014 (KoLRI 023395 sub Lecanora); the same locality, growing together with Caloplaca aequata and C. aff. subconcilians. Coll.: Kondratyuk, S. Y. (SK-07), (140895-2), 21.06.2014 (KoLRI 023410 sub Caloplaca aff. subconcilians); Jeju-si, Chuja-do Island, Chuja-myeon, Yecho-ri, Front Rood of Bokryusu, on rock, growing together with Amandinea punctata and Lecania rinodinoides. Lat.: $33^{\circ} 57^{\prime}$ 07.2" N; Long.: $126^{\circ} 19^{\prime} 13.08^{\prime \prime}$ E; Alt.: ca 33 m a.s.l. Coll.: Halda, J. P. (141110), 21.06 .2014 (KoLRI 023671 sub Amandinea punctata). - Gyeongsangnam-do province: Tongyeong-si, Salyang Island. Lat.: $34^{\circ} 51^{\prime} 0.96^{\prime \prime} \mathrm{N}$; Long.: $128^{\circ} 11^{\prime}$ 59.10" E; Alt.: ca $300 \mathrm{~m}$ a.s.l., on rock, growing together with Buellia sp. Coll.: Wang, X. Y., Joshi, Y., Han, J. H. (110056), 20.04.2011 (KoLRI 012879 sub Buellia); Geoje-si, Geoje Island, seaside, on rock, growing together with Buellia sp. Lat.: 34 51' 08.07" N; Long.: $128^{\circ} 44^{\prime} 01.12^{\prime \prime}$ E; Alt.: ca $1 \mathrm{~m}$ a.s.l. Coll.: Wang, X. Y., Ryu, J. A. (110094), 21.04.2011 (KoLRI 013311 sub Buellia); Geoje-si, Geoje Island, seaside, on rock, growing together with Buellia sp., Fuscidea coreana and Lichenothelia sp. Lat.: $34^{\circ} 51^{\prime}$ 08.07" N; Long.: $128^{\circ} 44^{\prime}$ 01.12" E; Alt.: ca $1 \mathrm{~m}$ a.s.l. Coll.: Wang, X. Y., Ryu, J. A. (110096), 21.04.2011 (KoLRI 013313 sub Buellia). - Jeollanam-do province: Wando-gun, Bogil Island, Bogil-myeon, Jeongdong-ri, seaside, on rock, growing together with Buellia sp. and Fuscidea coreana. Lat.: 34' 10' 18.31" N; Long.: 126 32' 18.79" E; Alt.: ca 11 m a.s.l., Coll.: Joshi, Y., Jeon, H. S., Jeong, M. H. (100254) 06.02.2010 (KoLRI 011762 sub Buellia).

Fuscidea coreana S. Y. Kondr., L. Lőkös et J.-S. Hur, spec. nova (Fig. 3)

Mycobank no.: MB 814518.

Similar to Fuscidea mollis, but differs in having smaller apothecia, with flat apothecium disc, in having whitish pruine apothecia, in having smaller (especially narrower) and 8-like shaped ascospores. 
Type: South Korea: Gyeongsangnam-do province, Hadong-gun, Hwagae-myeon, Chiri Mts, Byeoksoryeong-Seseok, on rock, growing together with Buellia sp. and Ochrolechia sp. Lat.: $35^{\circ} 19^{\prime} 40.74^{\prime \prime}$ N; Long.: $127^{\circ} 39^{\prime} 31.32^{\prime \prime}$ E; Alt.: ca 1,346 m a.s.l. Coll.: Joshi, Y., Wang, X. Y., Hur, J. Y. (091392), 15.10.2009 (holotype: KoLRI 011309 sub Buellia).

Thallus to 1-2 $\mathrm{mm}$ across but may form larger aggregations, crustose, rather thick, continuous to cracked, with distinct 'pseudoareoles' to $0.6-1 \mathrm{~mm}$ across, grayish to dark greyish. In section thallus to 100-150 $\mu \mathrm{m}$ thick, cortical layer to 10-15 thick, somewhat indistinct, of 'textura intricata'. Hypothallus black or line in contact with the other crustose lichens, to $0.2-0.3 \mathrm{~mm}$ wide, black present.

Apothecia 0.3-0.7(-0.8) mm diam., in section $0.15-0.35 \mathrm{~mm}$ thick, biatorine or seem to be zeorine when own margin more or less grayish, concolorous with thallus, from sides [at the outer edges] (while in section biatorine and outer layer of exiple to $25-30 \mu \mathrm{m}$ thick hyaline, while darkening into inner portion), sessile; own margin to $0.05(-0.1) \mathrm{mm}$ wide, somewhat undulating, dark greyish or blackish grey, slightly darker of thallus to brown-black and contrasting to thallus, arising level of disc; disc flat, dull brownish black seem to be with somewhat very weak whitish pruine; in section biatorine, true exciple to $30-50 \mu \mathrm{m}$ thick in the uppermost lateral portion, to $40-70 \mu \mathrm{m}$ thick in lower lateral portion, with outermost layer to 20-25 $\mu \mathrm{m}$ wide brownish while the inner portion hyaline, to $50-80(-100) \mu \mathrm{m}$ thick in basal portion, hyaline, only outer layer brownish-blackish; thalline exciple absent, algae present only in basal portion of apothecium or in thallus; hymenium (50-)60-70 $\mu \mathrm{m}$ high, somewhat yellowish; epihymenium to $15 \mu \mathrm{m}$ thick, brown; paraphyses usually becoming brown in the upper portion, swollen towards the tips, to 5-6(-7) $\mu \mathrm{m}$ thick; subhymenium to 70-100(-130) $\mu \mathrm{m}$ thick, hyaline to yellowish in the upper part, oil droplets mainly not numerous (or sometimes numerous), to $3 \mu \mathrm{m}$ diam. present; asci 8-spored, 40-45 × 12-13 $\mu \mathrm{m}$; ascospores simple, rarely 1 -septate, hyaline, mainly constricted at the equatorial portion, i.e.; 8-like shaped (better seen in K) to ellipsoid or one cell/half slightly larger of the other, $(6.5-) 7-8(-10) \times 3.5-4.5(-5) \mu \mathrm{m}$ (measurements in $\mathrm{K})$.

Chemistry: Thallus and medulla $\mathrm{K}-, \mathrm{C}-, \mathrm{KC}-, \mathrm{P}-, \mathrm{UV}+$ white (divaricatic acid present).

Ecology: It grows on rock, often growing together with Lecanora spp., Pertusaria spp., and other crustose lichens.

Etymology: It is named after South Korea, Eastern Asia, where type collection of this species was done.

Distribution: It is known from a number of localities from South Korea, Eastern Asia. 

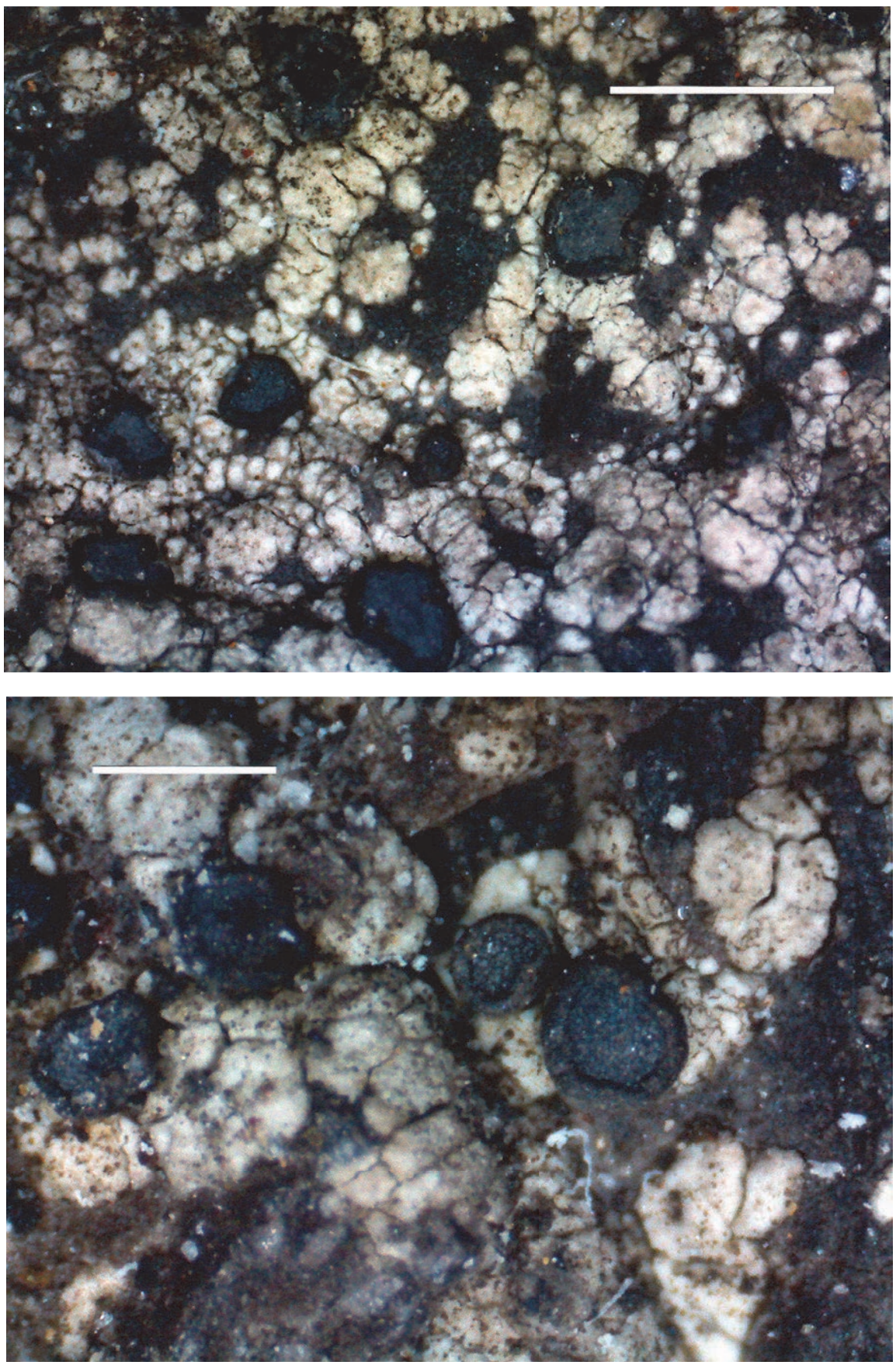

Fig. 3. Fuscidea coreana, general habit (holotype). Scale $2 \mathrm{~mm}$ (top) and $1 \mathrm{~mm}$ (bottom) (photo: S. Kondratyuk) 
Taxonomic notes: Fuscidea coreana is characterised by grey thallus with usually well distinct black hypothallus and brown to dark brown apothecia, which often seem to be zeorine or even lecanorine, as well as by very small to 8-like shaped ascospores.

After having very small ascospores and the presence of divaricatic acid $(\mathrm{UV}+)$ Fuscidea coreana is similar to Fuscidea mollis (Wahlenb.) V. Wirth et Vězda, rare in Europe and North America species, but differs in having smaller apothecia $(0.3-0.7 \mathrm{~mm} v .0 .3-1 \mathrm{~mm}$ diam.), with flat (v. plane to slightly convex) apothecium disc, in having whitish pruine ( $v$. epruinose, sometimes glossy) apothecia, in having smaller (especially narrower) and 8-like shaped ascospores $((6.5-) 7-8(-10) \times 3.5-4.5(-5) \mu \mathrm{m} v .8-9.5 \times 5.5-6.5 \mu \mathrm{m}$, broadly ellipsoid).

Fuscidea coreana is also similar to F. cyanoides (Ach.) V. Wirth et Vězda, which is common in the Northern Hemisphere, in having the same sessile, lecideine apothecia with a well-developed excipulum, and small, simple or 1-septate spores, but differs from it in having esorediate thallus and smaller apothecia (0.3-0.7 $\mathrm{mm} v$. to $1.5 \mathrm{~mm}$ diam.), in having persistent true exciple, in having shorter, somewhat narrower and 8-like shaped ascospores ((6.5-)7$8(-10) \times 3.5-4.5(-5) \mu \mathrm{m} v .9 .5-13 \times 5-5.5(-6) \mu \mathrm{m}$, kidney-bean-shaped), and in having divaricatic acid, as well as in the lack of soredia, thalline exciple and fumarprotocetraric acid.

From Fuscidea submollis M. Inoue, alpine species of Japan growing on noncalcareous rocks, F. coreana differs in having grayish to dark grayish thallus (v. ash-grey with brown tinge) and much thinner thallus (v. bullate-areolate or verrucose-areolate), in having much narrower ascospores $((6.5-) 7-8(-10) \times$ $3.5-4.5(-5) \mu \mathrm{m} v \cdot 7.5-10 \times 5-6 \mu \mathrm{m})$, as well as in the lack of I+ intense violetblue reaction of medulla (Inoue 1981).

Additional specimens examined: South Korea. Jeju-do province: Jeju-si, Cheju-do Island, Hangyeong-myeon, Sinchang-ri, seashore road, on rock, growing together with Buellia chujadoensis. Lat.: $33^{\circ} 20^{\prime} 31.6^{\prime \prime} \mathrm{N}$; Long.: $126^{\circ} 10^{\prime} 12.08^{\prime \prime} \mathrm{E}$; Alt.: ca $82 \mathrm{~m}$ a.s.l. Coll.: Lőkös, L. (140207-2), 18.06.2014 (KoLRI 022580); Jeju-si, Chuja-do Island, Chuja-myeon, Sinyang-1-ri, seashore of Mojini-mongdol, on rock, growing together with Enterographa sp. Lat.: $33^{\circ} 56^{\prime} 44.9^{\prime \prime}$ N; Long.: $126^{\circ} 20^{\prime} 03.01^{\prime \prime}$ E; Alt.: ca $57 \mathrm{~m}$ a.s.l. Coll.: Kondratyuk, S. Y. (SK07), (140879-1), 21.06.2014 (KoLRI 023381); Jeju-si, Chuja-do Island, Chuja-myeon, Yecho-ri, Mt Dondae, on rock, growing together with Buellia chujadoensis and Lecanora lojkahugoi. Lat.: 33 56' 53.9" N; Long.: $126^{\circ} 19^{\prime}$ 26.7" E; Alt.: ca 164 m a.s.l. Coll.: Halda, J. P. (140821), 20.06.2014 (KoLRI 023306 sub Buellia). - Gyeongsangnam province: Geoje-si, Geoje Island, seaside, on rock, growing together with Buellia chujadoensis, Buellia sp. and Lichenothelia sp. Lat.: $34^{\circ}$ 51' 08.07" N; Long.: 128 44' 01.12" E; Alt.: ca $1 \mathrm{~m}$ a.s.l. Coll.: Wang, X. Y., Ryu, J. A. (110096), 21.04.2011 (KoLRI 013313 sub Buellia); Tongyeng-si, Yokji-myeon, Donghang-ri Saen-gil, Yokji-do, coast, on rock. Lat.: 34 37' 34.04" N; Long.: $128^{\circ} 16^{\prime} 16.02^{\prime \prime}$ E; Alt.: ca $32 \mathrm{~m}$ a.s.l. Coll.: Oh, S.-O., Jayalal, U., Park, J. S., Ryu, J. A. (120889), 11.05.2012 (KoLRI 015887). - Jeollanam-do province: Jangheung-gun, Gwansan-eup, Okdang-ri, Cheongwansan Mts, along the tourist track No. 2, on rocks, growing together with Graphis cf koreana and Hale- 
cania subalpivaga. Lat.: 34 32' 22.93" N; Long.: 126 55' 11.16" E; Alt.: ca 495 m a.s.l. Coll.: Kondratyuk, S. (SK-82), Lőkös, L. (150359), 23.06.2015 (KoLRI 033954); the same locality, growing together with Lecanactis subdilleniana, (150358), (KoLRI 033953); Shinan-gun, Bogil Island, on rock. Lat.: $34^{\circ} 10^{\prime} 42.48^{\prime \prime} \mathrm{N}$; Long.: $126^{\circ} 32^{\prime}$ 02.22" E; Alt.: ca $12 \mathrm{~m}$ a.s.l. Coll.: Wang, X. Y., Ryu, J. A. (110652), 23.06.2011 (KoLRI 013680); the same locality, growing together with Dirinaria applanata and Lecanora sp. Coll.: Wang, X. Y., Ryu, J. A. (110668), 23.06.2011 (KoLRI 013696 sub Lecanora); Wando-gun, Bogil Island, Bogil-myeon, Buyongri, Mt Gyeokja, Keungiljiae (Suribong), on rock, growing together with Buellia sp. Lat.: $34^{\circ}$ 08' 34.3" N; Long.: 126 33' 25.7" E; Alt.: ca 255 m a.s.l. Coll.: Joshi, Y., Jeon, H. S., Jeong, M. H. (100086), 05.02.2010 (KoLRI 011582 sub Buellia); Wando-gun, Bogil Island, Bogil-myeon, Jeongdong-ri, seaside, on rock, growing together with Buellia chujadoensis, and Buellia sp. Lat.: $34^{\circ} 10^{\prime} 18.31^{\prime \prime} \mathrm{N}$; Long.: $126^{\circ} 32^{\prime} 18.79^{\prime \prime}$ E; Alt.: ca $11 \mathrm{~m}$ a.s.l. Coll.: Joshi, Y., Jeon, H. S., Jeong, M. H. (100254), 06.02.2010 (KoLRI 011762 sub Buellia); Wando-gun, Saengil-do, Saengil-myeon, Geumgok-ri coast, on rock. Lat.: $34^{\circ} 20^{\prime} 02.02^{\prime \prime}$ N; Long.: $126^{\circ} 57^{\prime} 51.02^{\prime \prime}$ E; Alt.: ca 7 m a.s.l., Coll.: Jayalal, U., Park, J. S., Ryu, J. A. (120177), 18.04.2012 (KoLRI 014771); the same locality, 120178 (KoLRI 014772); Wando-gun, Saengil-do, Saengil-myeon, Geumgok beach coast, on rock, growing together with Pertusaria subobductans. Lat.: $34^{\circ}$ 18' 40.02" N; Long.: 126 57' 54.03" E; Alt.: ca 4 m a.s.1., Coll.: Jayalal, U., Park, J. S., Ryu, J. A. (120231), 18.04.2012 (KoLRI 014826 sub Pertusaria subobductans); Yeosu-si, Geumoh-do, Nam-myeon, Yusong-ri coast, on rock. Lat.: 34 31' 55.03" N; Long.: $127^{\circ} 45^{\prime}$ 55.05" E; Alt.: ca 11 m a.s.l. Coll.: Jayalal, U., Park, J. S., Ryu, J. A. (120534), 27.04.2012 (KoLRI 015526).

Fuscidea extremorientalis S. Y. Kondr., L. Lőkös et J.-S. Hur, spec. nova (Fig. 4)

Mycobank no.: MB 814519.

Similar to Fuscidea maccarthyi, but differs in having thinner lighter thallus (greyish or greenish grey, v. dull olive-brown), in having thinner excipulum wall, in having much thinner and lacking oil subhymenium, in having less widened apices of paraphyses, in having ellipsoidal and sphaerical, much wider ascospores, as well as in the lack of sekikaic and 4'-O-demethyl-sekikaic acid.

Type: South Korea: Jeju-do province, Jeju-si, Cheju-do Island, Mt Halla, Seongpanak Trail, on bark of Prunus sp. trunk. Lat.: $33^{\circ} 22^{\prime} 48.44^{\prime \prime}$ N; Long.: $126^{\circ} 35^{\prime}$ 26.70" E; Alt.: ca 1025 m a.s.l. Coll.: Kondratyuk, S. Y. (212659), Lőkös, L., Oh, S.-O., Joshi, S. (121871), 06.07.2012 (holotype: KoLRI 016850).

Thallus to several $\mathrm{cm}$ across but may form larger aggregations, crustose, from very thin and almost indistinct to more or less thicker in the central portion (around apothecia), continuous to slightly warty or somewhat undulating in the centre, grayish to somewhat dark greenish grey, distinct owing to numerous dark brown or blackish apothecia somewhat aggregated in groups. In section thalus to $50-70 \mu \mathrm{m}$ thick, cortical layer indistinct or very 
thin 5-10 $\mu \mathrm{m}$ thick, of 'textura intricata'. Hypothallus or black line at the edge of thallus not observed.

Apothecia 0.15-0.3(-0.4) $\mathrm{mm}$ diam., in section to $0.14 \mathrm{~mm}$ thick, lecideine, sessile, roundish; disc and own margin usually concolorous, black; disc more or less persistently plane, black or somewhat dull black, margin arising highly above the substrate level of disc, black or brownish black, somewhat shining/glossy; in section true exciple to 10-20(-30) $\mu \mathrm{m}$ thick in the uppermost lateral portion with outer uppermost portion blackish brown to black and brownish or brown inner portion, to $25-30(-50) \mu \mathrm{m}$ thick in lower lateral portion, light brown, to $30-40 \mu \mathrm{m}$ thick in basal portion, light brown in portion close to the edge of apothecium and hyaline or straw towards the centre or not developed in the centre; thalline exciple absent, algae present only below apothecium in the thallus; hymenium (50-)60-90 $\mu \mathrm{m}$ high, hyaline or somewhat slightly olive-brown in places; epihymenium to $20-25 \mu \mathrm{m}$ thick, brownish greenish blackish with distinct brown pigment grains dissolving in $\mathrm{K}$ and intensifying olive; paraphyses usually becoming brown in the upper portion, almost not swollen towards the tips, to $2-3 \mu \mathrm{m}$ thick; subhymenium 20-30 $\mu \mathrm{m}$ thick, hyaline to yellowish or somewhat pale brownish in places, oil droplets absent; asci of Fuscidea-type, 8-spored, often ascospores varying in size considerably within the same ascus, seem to be densely agglutinated in ascus; ascospores simple, rarely seem to be 1-septate, hyaline, mainly ellipsoid to spherical, (8-)10-15(-19) × (8-)9-11(-14) $\mu \mathrm{m}$, ascospore wall to $1.5(-1.8) \mu \mathrm{m}$ thick (measurements in water).

Chemistry: Thallus K-, C-, KC-, P-, UV-.

Ecology: It grows on bark of trees.

Etymology: It is named after Far Eastern region of Asia, where type collection was done.

Distribution: So far known only from type collection, i.e. Cheju-do Island, South Korea, Eastern Asia.

Taxonomic notes: This species is characterised by the rather large ellipsoid to sphaerical ascospores with thick wall, asci of Fuscidea-type, blackish lecideine apothecia as well as an epiphytic habitat.

Fuscidea extremorientalis is similar to F. maccarthyi Kantvilas, endemic to South Eastern N.S.W. of Australia species, growing on sandstone, but differs in having lighter (grayish or greenish grey, $v$. dull olive-brown) and thinner (50-70 $\mu \mathrm{m} v .90-200 \mu \mathrm{m}$ thick) thallus, in having thinner excipulum wall (10$30 \mu \mathrm{m} v$. in section $40-50 \mu \mathrm{m}$ thick), in having much thinner subhymenium ( $v$. hypothecium 100-200 $\mu \mathrm{m}$ thick) and lacking oil (inseprsed with oil droplets 2-7 $\mu \mathrm{m}$ diam.), in having less widened apices of paraphyses $(2-3 \mu \mathrm{m} v$. apices expanded to $3-6 \mu \mathrm{m}$ wide), in having ellipsoidal and sphaerical ( $v$. ellipsoidal or bean-shaped, sometimes very markedly so), and much larger (especially 

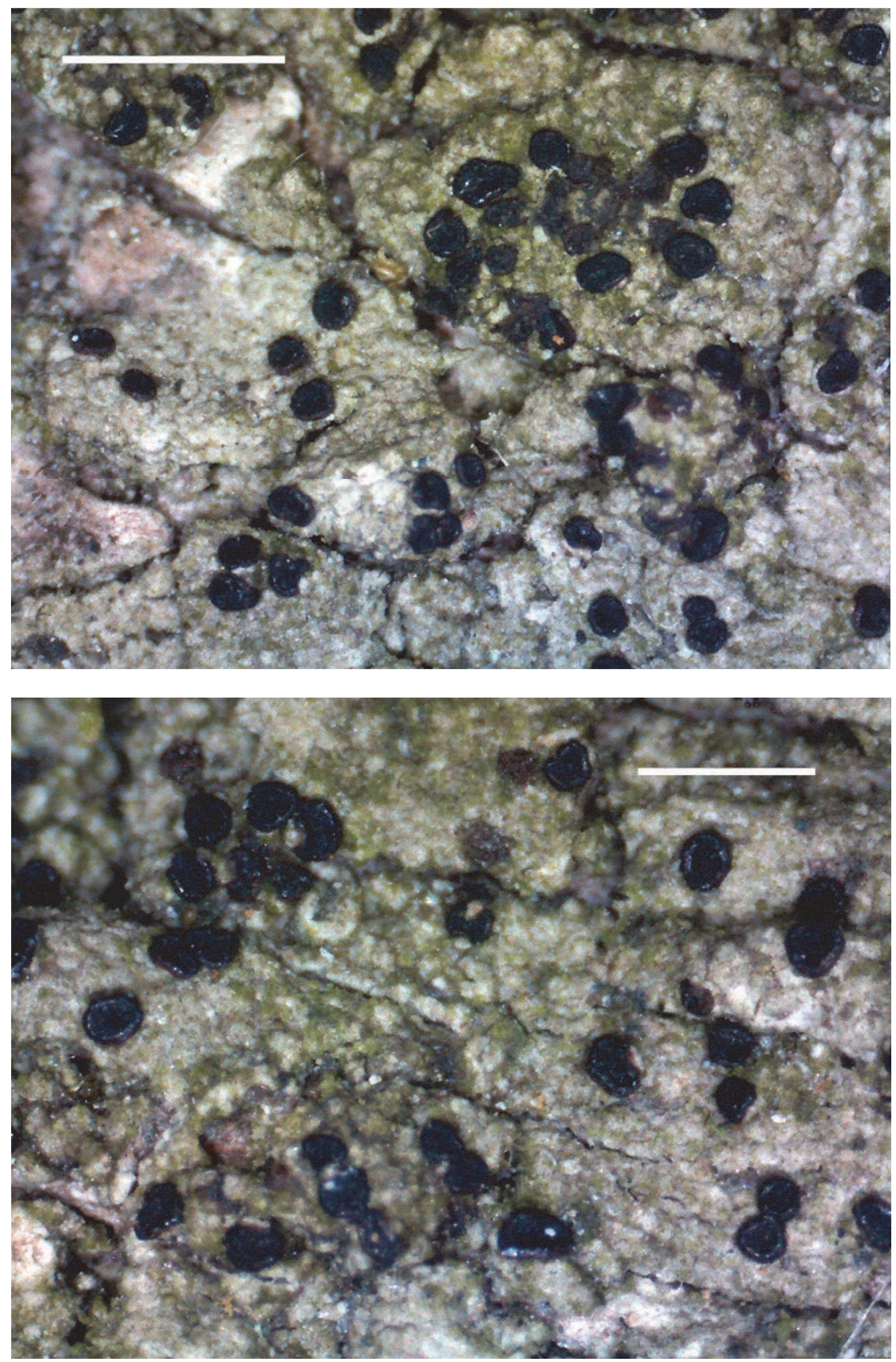

Fig. 4. Fuscidea extremorientalis, general habit (holotype). Scale $2 \mathrm{~mm}$ (top) and $1 \mathrm{~mm}$ (bottom) (photo: S. Kondratyuk) 
wider) ascospores (10-15 × 9-11 $\mu \mathrm{m} v \cdot 9-13 \times 4-6 \mu \mathrm{m})$, as well as in the lack of sekikaic and 4'-O-demethyl-sekikaic acid (Kantvilas 2004a, b).

After having UV- thallus, sessile apothecia and absence of soralia this material can be keyed as Fuscidea austera (Nyl.) P. James, central European mountain species, growing on sheltered, vertical siliceous rocks, but Fuscidea extremorientalis differs in having another colour of thallus ( $v$. grey to chocolate-brown), in having smaller apothecia (0.15-0.3(-0.4) v. 0.5-2 mm diam.), in the lack of pruina ( $v$. at times more or less sparingly pruinose); in having dark brown exciple and dark blackish-greenish epithecium ( $v$. true exciple brown, often paler than disc, at times partly piebald), in having much larger ascospores $(10-15 \times 9-11 \mu \mathrm{m} v .9-11 \times 6.5-8 \mu \mathrm{m})$, as well as in the lack of UV reaction of thallus $(v$. UV+ bluish white (divaricatic acid confined to apothecia)), as well as in its ecology.

In general habit this species is similar to Amandinea punctata (Hoffm.) Coppins et Scheid. in having grayish to greenish grey thallus and blackish lecideine apothecia, but Fuscidea extremorientalis differs in having simple hyaline ascospores, Fuscidea-type of ascus, and hyaline exciple in central part and hyaline subhymenium.

Hafellia extremorientalis S. Y. Kondr., L. Lőkös et J.-S. Hur, spec. nova (Fig. 5)

Mycobank no.: MB 814520.

Similar to Hafellia pleiotera, but differs in having larger apothecia, in having wider exciple, in having hyaline outer layer and dark brown inner one, in having much thinner subhymenium, in having narrower paraphyse tips, in having asci with more than 16 ascospores, as well as in the lack of K+ violet reaction of epihymenium, and in the lack of connorstictic and methylpseudonorstictic acid.

Type: South Korea: Gangwon-do province, Chuncheon-si, Buksan-myeon, Jogyo-ri, Mt Maebong, on bark, growing together with Graphis sp., Lecanora sp., Micarea sp. and Scoliciosporum chlorococcum damaged by Intralichen sp. Lat.: $37^{\circ} 54^{\prime} 55.86^{\prime \prime}$ N; Long.: $127^{\circ} 59^{\prime} 0.48^{\prime \prime}$ E; Alt.: ca 714 m a.s.l., Coll.: Wang, X. Y., Jeon, H. S., Lü, L., Ryu, J. A. (100637), 26.05.2010 (holotype: KoLRI 012376).

Thallus to 1-2 $\mathrm{cm}$ across or may form larger aggregations, crustose, from very thin and almost indistinct to well distinct and rather thick, continuous, upper surface from smooth to somewhat uneven or verruculose, whitish to whitish grey or grey. Hypothallus / edge in contact with the other crustose lichens black, to $0.1(-0.2) \mathrm{mm}$ wide, sometimes not observed. 
Apothecia (0.3-)0.4-1 mm diam., in section $0.17 \mathrm{~mm}$ thick, lecideine, immersed into thallus at first soon becoming sessile, mainly scattered and distant, regularly rounded rarely aggregated in groups to $3(-5)$ and pressed; disc concave at first, than plane, often somewhat glossy, brown dark at first but soon becoming black; own margin to $0.08-0.1 \mathrm{~mm}$ wide, well distinct, usually arising the level of disc, permanent, becoming somewhat undulating at overmature, black; in section true exciple to $40-50(-60) \mu \mathrm{m}$ thick in the uppermost lateral portion and to $50-60(-80) \mu \mathrm{m}$ thick in lower lateral portion, outermost portion to 20-30 $\mu \mathrm{m}$ thick hyaline, while dark brown to black brown in the inner portion, to (35-)50-120 $\mu \mathrm{m}$ thick in basal portion, $\mathrm{K}-$; thalline exciple absent; hymenium (70-)80-100 $\mu \mathrm{m}$ high, richly inspersed with oil; epihymenium to $15-25 \mu \mathrm{m}$ thick, olive brown, somewhat intensifying olive in $\mathrm{K}$; paraphyses rather thin, 1.5-2 $\mu \mathrm{m}$ diam., almost not swollen or only slightly swollen towards the tips, to 2-3 $\mu \mathrm{m}$ thick; subhymenium 50-60 $\mu \mathrm{m}$ thick, olive brown to blackish brown, asci (8-)16-24-spored; ascospores 1-septate, olive brown to blackish brown, with almost lighter apices, elongated ellipsoid to fusiform, with more or less rounded ends, and slightly constricted at the septum, sometimes distinctly guttulate or collapsed and closely adglutinated in asci, mainly straight or sometimes slightly curved, and (11-)13-18(-20) $\times$ (4.5-)5.5-7(-8.5) $\mu \mathrm{m}$, while smaller ascospores (8-)9-11 × 3.5-4(5-) often observed in the same apothecium / section too.

Chemistry: Thallus $\mathrm{K}+$ yellow, epihymenium and exciple of apothecium $\mathrm{K}+$ intensifying olive.

Ecology: It grows on bark of deciduous trees.

Etymology: It is named after "Far East" name for Eastern Asian region.

Distribution: So far known from scattered localities in South Korea, Eastern Asia.

Taxonomic notes: Hafellia extremorientalis is similar to widely distributed tropical and subtropical species Hafellia pleiotera (Malme) Marbach, but differs in having larger apothecia ((0.3-)0.4-1 $\mathrm{mm} v .0 .3-0.4 \mathrm{~mm}$ diam.), in having wider exciple (50-120 $\mu \mathrm{m} v$. 20-30 $\mu \mathrm{m}$ thick), in having hyaline outer layer and dark brown inner one ( $v$. black outer and lighter inner), in having much thicker subhymenium (50-60 $\mu \mathrm{m} v$. to $100 \mu \mathrm{m}$ thick), in having narrower paraphyse tips (2-3 $\mu \mathrm{m} v$. 3-3.5 $\mu \mathrm{m}$ diam.), in having asci with more than 16 ascospores as well as in the lack of $\mathrm{K}+$ violet reaction of epihymenium, and in the lack of connorstictic and methylpseudonorstictic acids (in the lack of $\mathrm{K}+$ yellow to red reaction of thallus).

After key to corticolous and lignicolous species of Hafellia with 2-celled ascospores (Etayo and Marbach 2003) this material can be keyed only to $H$. pleiotera. However, after Marbach (2000) this species differs in having epihymenium $\mathrm{K}+$ becoming violet. Asci containing more than 16-spores were 

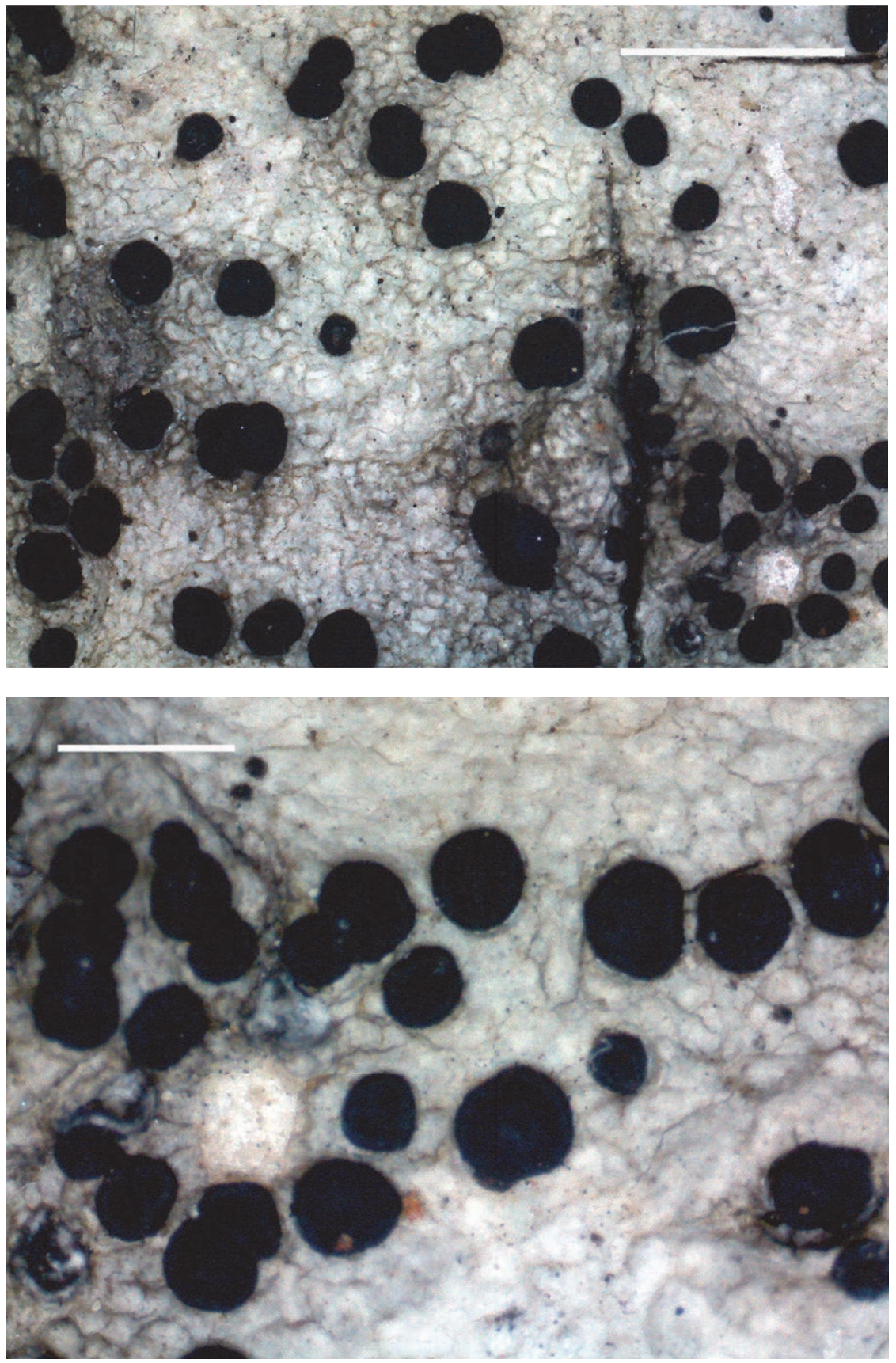

Fig. 5. Hafellia extremorientalis, general habit (holotype). Scale $2 \mathrm{~mm}$ (top) and $1 \mathrm{~mm}$ (bottom) (photo: S. Kondratyuk) 
recorded for H. pleiotera by Vainio (after Räsänen 1940) and Sheard (1992). However, these differences discussed only at infraspecific level of $H$. pleiotera.

After the key to the North American species of Hafellia (Sheard 1992) $H$. pleiotoma (as H. bahiana var. pleiotoma (Malme) Sheard) is characterised by the ascospores (12-)16 or 32 per ascus, but they are much narrower of Korean specimens $(v$. (10.8-)13.2-14.2(-16.6) $\times(4.2-) 5.0-5.3(-6.1) \mu \mathrm{m}$, as well as callisporoid structure being most evident in the larger ascospores).

Lecidea pleiophoroides Nyl. can be an earlier name for this taxon, but type specimen described by Räsänen (1940: 141) differs in having K- thallus and smaller size of ascospores. It should be mentioned that Hafellia subnexa ( $\mathrm{Nyl}$.) Marbach includes Lecidea pleiophoroides Nyl. as synonym, while the latter (as Buellia pleiophoroides (Nyl.) Vain. in both Kurokawa 2003 and Harada et al. 2004) was recorded in Japanese checklists together with Hafellia subnexa (as Buellia subnexa (Nyl.) Vain.).

Additional specimens examined: South Korea. Chungcheongnam-do province: Seosan-si, Palbong-myeon, Palbong-san Mts, on Quercus bark. Lat.: $36^{\circ} 48^{\prime} 40.7^{\prime \prime} \mathrm{N}$; Long.: $126^{\circ}$ 22' 20.6" E; Alt.: ca 194 (335) m a.s.l. Coll.: Hur, J.-S. (061230), 04.11.2006 (KoLRI 005618). - Ulsan-do province: Ulju-gun, Sangbuk-myeon, Gan-Wolsan, on Quercus bark. Lat.: 35³2' 42.7" N; Long.: 129 04' 04.4" E; Alt.: ca 655 m a.s.l. Coll.: Hur, J.-S. (070917-1), 04.11.2007 (KoLRI 007718-1).

Hafellia pseudosubnexa S. Y. Kondr., L. Lőkös et J.-S. Hur, spec. nova (Fig. 6)

Mycobank no.: MB 814521.

Similar to Hafellia subnexa, but differs in having larger apothecia, in having wider exciple and dark outer layer, in having asci mainly with 12 ascospores, in having much longer ascospores, as well as in having $K+$ yellow reaction (not becoming red later) of thallus.

Type: South Korea: Gangwon-do province, Chuncheon-si, Buksan-myeon, Jogyo-ri, Mt Maebong, on Quercus bark, growing together with Lecanora saligna (new to Korea). Lat.: $37^{\circ} 54^{\prime} 38.28^{\prime \prime}$ N; Long.: $127^{\circ} 58^{\prime} 54.48^{\prime \prime}$ E; Alt.: ca $610 \mathrm{~m}$ a.s.l. Coll.: Wang, X. Y., Jeon, H. S., Lü, L., Ryu, J. A. (100565), 26.05.2010 (holotype: KoLRI 012321); the same locality, growing together with Biatora sp. and Rinodina sp., (100580), (isotype: KoLRI 012335).

Thallus to $3 \mathrm{~cm}$ across or may form larger aggregations, crustose, continuous, from very thin and almost indistinct in peripheral zone to well distinct and slightly thicker in the centre or almost the same thickness throughout, up- 
per surface from smooth to somewhat uneven or verruculose or cracked (seen at $\times 100$ and more), whitish to whitish grey. Hypothallus almost indistinct.

Apothecia (0.4-)0.6-0.8(-1) mm diam., in section 0.15-0.25(-0.3) $\mathrm{mm}$ thick, lecideine, at first immersed into thallus soon becoming sessile, mainly scattered and distant, regularly rounded rarely aggregated in groups; disc concave or plane, brownish black at first, than semiconvex to convex, black somewhat shiny; own margin at first well distinct, to $0.08-0.1 \mathrm{~mm}$ wide, uplifting above disc level, at overmature seem to be disappearing, while permanent, indistinct or seen as $0.05 \mathrm{~mm}$ wide, black; in section true exciple to 20$40(-50) \mu \mathrm{m}$ thick in the uppermost lateral portion and to 20-80(-90) $\mu \mathrm{m}$ thick in lower lateral portion, to $60-80(-110) \mu \mathrm{m}$ thick in basal portion, dark brown to black brown, $\mathrm{K}-$; thalline exciple absent; hymenium $90-100(-110) \mu \mathrm{m}$ high, richly inspersed with oil, regularly rounded oil droplets to $4 \mu \mathrm{m}$ diam. and irregular oil aggregations to 3-7 $\mu \mathrm{m}$ across in lower half of hymenium always observed; epihymenium to $15-20 \mu \mathrm{m}$ thick, blackish olive to dark olive brown, somewhat intensifying olive in $\mathrm{K}$; paraphyses rather thin, 1.5-2 $\mu \mathrm{m}$ diam., almost not swollen towards the tips, to 2-2.5 $\mu \mathrm{m}$ thick; subhymenium (20-)50-80(-100) $\mu \mathrm{m}$ thick, somewhat olive brown to blackish brown, $\mathrm{K}-$; asci (8-)10-12(-16?)-spored; ascospores 1-septate, olive brown to olive grey or olive black, very long, elongated ellipsoid to narrowly fusiform, with more or less rounded ends, and slightly constricted at the septum, mainly straight or sometimes slightly curved, and (14-)17-22(-23) × (5-)6-7(-8) $\mu \mathrm{m}$.

Chemistry: Thallus $\mathrm{K}+$ yellow, epihymenium and exciple of apothecium $\mathrm{K}+$ intensifying olive.

Ecology: It grows on bark of trees.

Etymology: It is named after similarities of this taxon to Hafellia subnexa.

Distribution: So far known from scattered localities in South Korea, Eastern Asia.

Taxonomic notes: Hafellia pseudosubnexa is similar to Hafellia subnexa (Nyl.) Marbach (nom. inval. non Ramboldia subnexa (Stirt.) Kantvilas et Elix), but differs in having larger apothecia (0.6-1 $\mathrm{mm} v$. 0.35-0.6 $\mathrm{mm}$ diam.), in having wider exciple and dark outer layer $(60-80(-110) \mu \mathrm{m} v .30-60 \mu \mathrm{m}$ wide, where outer to $30 \mu \mathrm{m}$ hyaline and inner brown), in having asci mainly with 10-12 ascospores ( $v$. mainly with 16 , sometimes with 12 or 8 ), in having much longer ascospores $((14-) 17-22(-23) \times(5-) 6-7(-8) \mu \mathrm{m} v$. (13-) $15-17 \times 6-7(-8)$ $\mu \mathrm{m})$, as well as in having $\mathrm{K}+$ yellow reaction of thallus ( $v . \mathrm{K}+$ yellow becoming red later).

Hafellia pseudosubnexa is characterised by that asci are very rarely seen in the section, there are very small amount of ascospores in the section, abortive simple ascospores in the same ascus often seen. A number of ascospores in the ascus is very difficult to identify (it is better seen on squashed slides). 

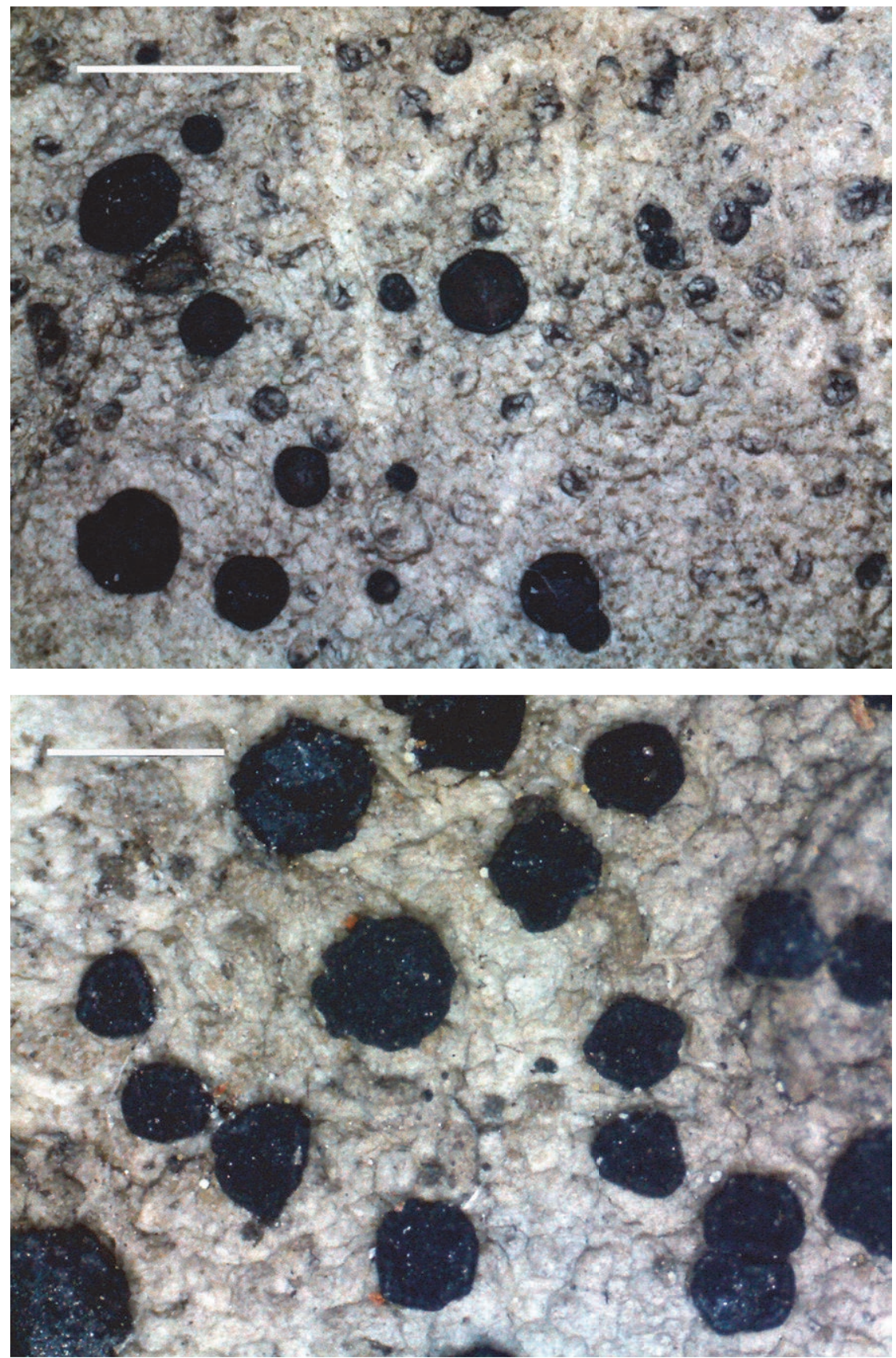

Fig. 6. Hafellia pseudosubnexa, general habit (holotype). Scale $2 \mathrm{~mm}$ (top) and $1 \mathrm{~mm}$ (bottom) (photo: S. Kondratyuk) 
Hafellia pseudosubnexa is similar to H. pleiotera (Malme) Marbach, known from Brazil, but differs in having larger apothecia (0.6-1 $\mathrm{mm} v .0 .3-0.4 \mathrm{~mm}$ diam.), in having wider exciple (v. 20-30 $\mu \mathrm{m}$ wide), in having asci mainly with 10-12 ascospores ( $v$. mainly with 16 , sometimes with 12 or 8$)$, in having much longer and wider ascospores ((14-)17-22(-23) $\times(5-) 6-7(-8) \mu \mathrm{m} v$. (12) $14-16(-18) \times 5-6(-7) \mu \mathrm{m})$, as well as in having $\mathrm{K}+$ yellow reaction of thallus (v. $\mathrm{K}+$ yellow becoming red later), as well as in the lack of $\mathrm{K}+$ violet reaction of epihymenium.

Additional specimens examined: South Korea: Gangwon-do province: Chuncheonsi, Buksan-myeon, Jogyo-ri, Mt Maebong, on bark, growing together with Caloplaca trassii and Catillaria sp. Lat.: $37^{\circ} 54^{\prime}$ 47.82" N; Long.: $127^{\circ}$ 59' 05.94" E; Alt.: ca 685 m a.s.l. Coll.: Wang, X. Y., Jeon, H. S., Lü, L., Ryu, J. A. (100614), 26.05.2010 (KoLRI 012359); Samcheok-si, Hajang-myeon, Mt Sambong, on bark of tree, growing together with Amandinea pseudomultispora, Biatora sp., Catillaria nigroclavata (new to Korea), Lecanora aff sambuci (new to Korea), Rinodina sp. and Scoliciosporum chlorococcum. Lat.: 37 $18^{\prime} 18.36^{\prime \prime} \mathrm{N}$; Long.: $128^{\circ} 56^{\prime} 22.08^{\prime \prime}$ E; Alt.: ca 930 m a.s.l., Coll.: Joshi, Y., Wang, X. Y., Ryu, J. A., Hur, J. Y. (090344), 15.05.2009 (KoLRI 010072); Sokcho-si, Mt Seorak, on bark, growing together with Amandinea pseudomultispora. Lat.: 38 09' 57.96" N; Long.: 128 27' 44.70" E; Alt.: ca 745 m a.s.l. Coll.: Joshi, Y., Wang, X. Y., Ryu, J. A. (090865), 24.05.2009 (KoLRI 010537). - Gyeongsangbuk-do province: Mungyeong-si, Sanbuk-myeon, Mt Kongduck, on bark, growing together with Biatora sp., Lecanora sp. and Micarea sp. Lat.: $36^{\circ} 45^{\prime} 13.0^{\prime}$ N; Long.: $128^{\circ} 16^{\prime} 07.1^{\prime}$ E; Alt.: ca $814 \mathrm{~m}$ a.s.l. Coll.: Hur, J.-S. (070809-1), 20.06.2007 (KoLRI 07646 sub Hafellia). - Gyeongsangnamdo province: Geochang-gun, Wicheon-myeon, Mt Geumwon, on Quercus bark, growing

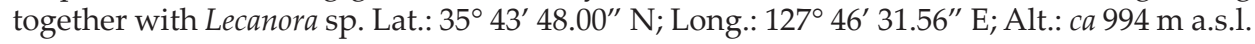
Coll.: Wang, X. Y., Jeon, H. S., Han, G. S. (100486), 25.06.2010 (KoLRI 012094); Hamyang-

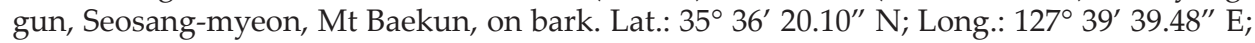
Alt.: ca 917 m a.s.l. Coll.: Wang, X. Y., Jeon, H. S., Han, G. S. (100413), 24.06.2010 (KoLRI 012042). - Jeollanam-do province: Goheung-gun, Jeomam-myeon, Mt Palyeong, on bark, growing together with Lecanora sp. Lat.: $34^{\circ} 37^{\prime} 54.30^{\prime \prime} \mathrm{N}$; Long.: $127^{\circ} 25^{\prime} 38.58^{\prime \prime} \mathrm{E}$; Alt.: ca 386 m a.s.l. Coll.: Wang, X. Y., Jeon, H. S., Han, G. S. (100285), 19.02.2010 (KoLRI 011796).

\section{Halecania subalpivaga S. Y. Kondr., L. Lőkös et J.-S. Hur, spec. nova} (Fig. 7)

Mycobank no.: MB 814522.

Similar to Halecania alpivaga, but differs in having smaller thalline granular warts, in having smaller apothecia, in having persistent thallis exciple, in having indistinct cortex, in having smaller ascospores, as well as in the lack of globose with pore-like disc apothecia at first.

Type: South Korea: Jeollanam-do province, Jangheung-gun, Gwansaneup, Okdang-ri, Cheongwansan Mts, along the tourist track No. 2, on rocks growing together with Fuscidea coreana and Verrucaria sp. Lat.: $34^{\circ} 32^{\prime} 22.93^{\prime \prime}$ N; 
Long.: $126^{\circ}$ 55' 11.16" E; Alt.: ca 495 m a.s.l. Coll.: Kondratyuk, S. (SK-82), Lőkös, L. (150324), 23.06.2015 (holotype: KoLRI 033919); the same locality, growing together with Fuscidea coreana, Lecanactis subdilleniana and Pertusaria flavicans, (150393), (isotype: KoLRI 033988).

Thallus to $1-2(-4) \mathrm{mm}$ across, very indistinct and very small, usually of very indistinct $0.2-0.4 \mathrm{~mm}$ across, dispersed, scattered, distant, convex and highly uplifted above the substrate level thalline areoles, distinguished only owing to apothecia present at the tips to densely aggregated grey-brown granules/warts or large granules or bullate with wart-like surface, sometimes to cushion-like warty aggregations; loosely attached to the substrate and can be easily exfoliated; upper surface dark brownish grey or dark brown; usually between other crustose lichen thalli, sometimes seems to be parasitic on other lichen thalli, while growing directly on rock surface too. Thallus thick in section without a distinct cortex, often coated with black granules, algal layer 50$65(-75) \mu \mathrm{m}$ thick, very thick, continuous; medullar lax to $40-50(-75) \mu \mathrm{m}$ thick.

Apothecia $0.15-0.22 \mathrm{~mm}$ diam., in section $0.12 \mathrm{~mm}$ thick, usually along and scattered, rarely in groups (2-3 together), lecanorine or sometimes zeorine in section, thalline margin to $50 \mu \mathrm{m}$ wide, brownish grey; disc somewhat concave, dark brown or blackish brown; in section thalline exciple very thin in the lateral portion, to $30-50 \mu \mathrm{m}$ thick and becoming thicker on underside, to 60-70 $\mu \mathrm{m}$ thick, without a distinct cortex, but often coated with black granules (or sometimes with very thin cortex to 5-7 $\mu \mathrm{m}$ thick forming by brown hyphal layer with rounded 4-5 $\mu \mathrm{m}$ diam., blackish cells (outgrowth)); algal zone to 20-25(-70) $\mu \mathrm{m}$ thick in the thalline margin, algal cells to 10-12 $\mu \mathrm{m}$ diam., true exciple to $30 \mu \mathrm{m}$ thick in the uppermost lateral portion and somewhat indistinct in lower lateral and basal portions, with dark brown outermost layer to $15 \mu \mathrm{m}$ thick; hymenium to $50 \mu \mathrm{m}$ high, hyaline, not inspersed with oil; epihymenium (7-)10-20(-25) $\mu \mathrm{m}$ thick, olive-blackish or brown, N-; paraphyses somewhat swollen towards the tips to $4 \mu \mathrm{m}$ diam., but without distinct brown cup-like formations asci 8-spored; ascospores 1-septated hyaline with well distinct halo to 1.3-2 $\mu \mathrm{m}$ thick in water, ascospores $9-11 \times(2.3-) 4-5.5 \mu \mathrm{m}$ (in water excluding halo).

Ecology: It grows on rocks or sometimes seems to be parasitic on other crustose lichen thalli.

Etymology: The species epithet reflects its similarity to Halecania alpivaga.

Distribution: It is known so far from several close localities in the southern part of mainland of South Korea, Eastern Asia.

Taxonomic notes: Halecania subalpivaga is similar to H. alpivaga (Th. Fr.) M. Mayrhofer, an arctic-alpine lichen known from calcareous rocks above $900 \mathrm{~m}$ alt., of Central Europe, Scandinavia, Spitzbergen, Greenland and North America, but differs in having smaller thalline granular warts (to $0.3 \mathrm{~mm}$ 

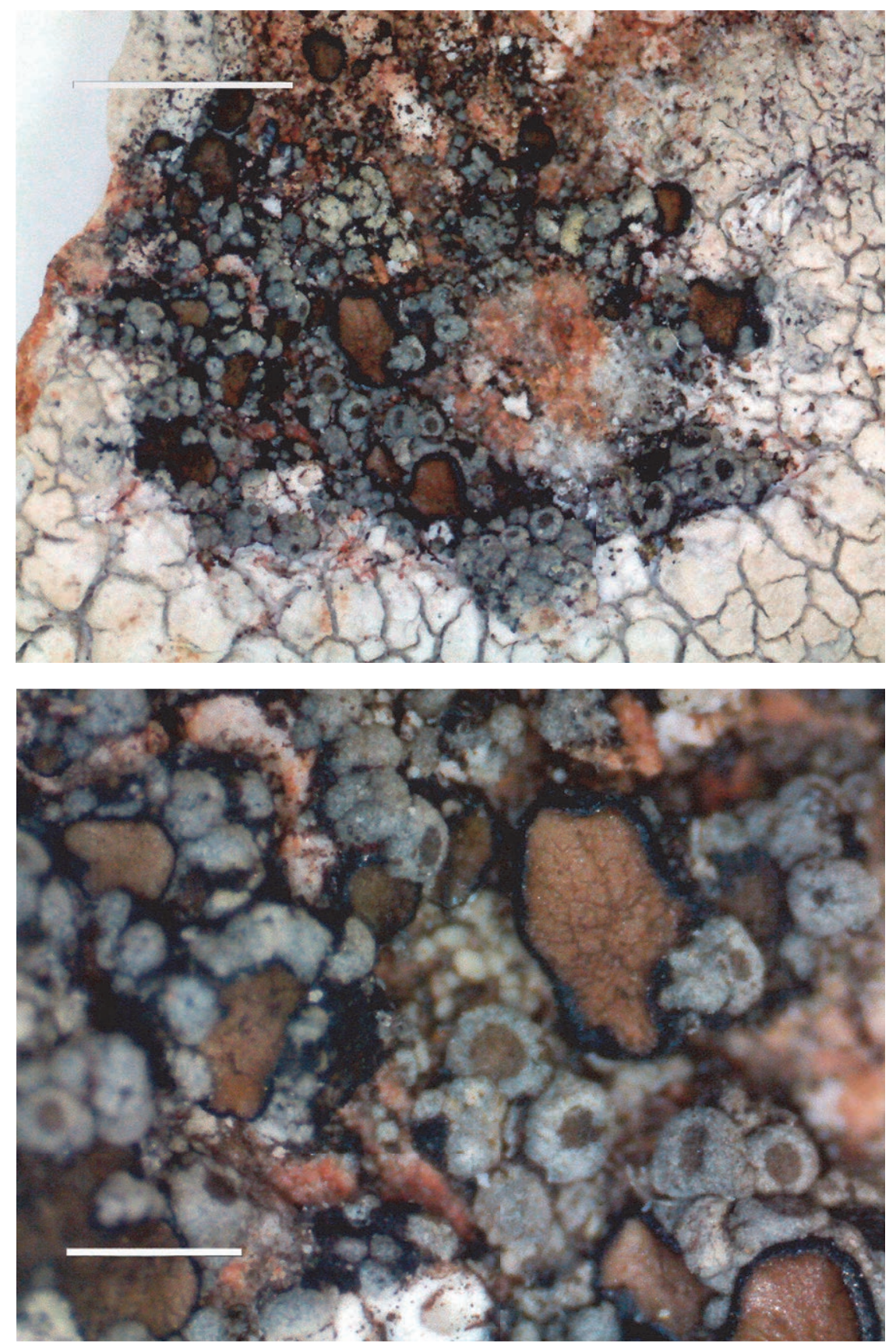

Fig. 7. Halecania subalpivaga, general habit (120154). Scale $2 \mathrm{~mm}$ (top) and $1 \mathrm{~mm}$ (bottom) (photo: S. Kondratyuk) 
thick $v$. to $1 \mathrm{~mm}$ thick), in having smaller apothecia $(0.15-0.22 \mathrm{~mm} v \cdot 0.3-0.88$ $\mathrm{mm}$ diam.), in having persistent thalline exciple ( $v$. occasionally receding in old apothecia), in having indistinct cortex ( $v$. the cortex distinct), in having smaller ascospores $(9-11 \times(2.3-) 4-5.5 \mu \mathrm{m} v$. 13.5-17.5(-22) × 5.5-7 $\mu \mathrm{m}$, after Mayrhofer 1987; and 14-17 × 5-7 $\mu \mathrm{m}$ (in water including perispore), 4.5-5 $\mu \mathrm{m}$ wide (in K, excluding perispore) (after Fletcher and Coppins 2009), as well as in the lack of globose with pore-like disc apothecia at first and in epilithic habit ( $v$. very often parasitic in cyanolichen community).

Halecania subalpivaga is similar to Halecania spodomela (Nyl.) M. Mayrhofer, known from slightly base-enriched siliceous rocks (e.g. granite) usually near the coast (but always away from the supralittoral zone) in Europe, and which is distinguished by the green $(\mathrm{N}+$ red) epihymenium, but differs from the latter taxon in having brown epihymenium, $\mathrm{N}-$, in having grey to dark grey thallus (v. white to pale grey), in having smaller and plane apothecia $(0.15-0.22 \mathrm{~mm} v$. $0.3-0.6 \mathrm{~mm}$ diam.) flat to slightly convex, in having lighter disc ( $v$. dark brown to black), in having thalline margin ( $v$. persistent or receding), in having smaller ascospores $(9-11 \times(2.3-) 4-5.5 \mu \mathrm{m} v .11 .5-15.5 \times 6-7.5 \mu \mathrm{m}$ after Mayrhofer 1987; and 10-13(-15) $\times 5-7.5 \mu \mathrm{m}$ in water including perispore and $4-5 \mu \mathrm{m}$ wide (in K excluding perispore), after Fletcher and Coppins 2009).

From recently described Halecania parasitica Aptroot et K. H. Moon from South Korea $H$. subalpivaga differs in having larger thallus $(1-2(-4) \mathrm{mm}$ across v. up to $1.5 \mathrm{~mm}$ diam.), in having larger thalline areoles $(0.2-0.4 \mathrm{~mm}$ across v. $0.1-0.2 \mathrm{~mm}$ in diam.), in having distinctly swollen towards the tips paraphyses, in having much smaller and especially narrower ascospores (9-11 $\times$ $(2.3-) 4-5.5 \mu \mathrm{m} v .11-12.5 \times 6.5-7 \mu \mathrm{m})$, and in having distinct halo in water, as well as in the lack of a thickened median septum of ascospores. Unfortunately original description of $H$. parasitica is rather poor (Aptroot and Moon 2015), and any chemical data or measurements of apothecium details are missing. It produces additional troubles with comparison of these taxa. The parasitic habit and Rinodina-like apothecia mentioned as main characters of Halecania parasitica are the same characteristic features of Halecania subalpivaga, too. Furthermore, after measurements of ascospores Halecania parasitica is within variation of $H$. spodomela (see above), however, epihymenium reaction with $\mathrm{N}$ is not mentioned in original description of $H$. parasitica.

Additional specimens examined: South Korea. Jeollanam-do province: Wandogun, Yaksan-myeon, Deugam-ri, Udury coast, Joyak-do, on rocks growing together with Yoshimuria aff galbina and Lecanora sp. Lat.: 34 21' 36.07" N; Long.: 126 53' 27.03" E; Alt.: ca 3 m a.s.l. Coll.: Jayalal, U., Park, J.-S., Ryu, J. A. (120154), 18.04.2012 (KoLRI 014748 sub Yoshimuria aff galbina); Jangheung-gun, Gwansan-eup, Okdang-ri, Cheongwansan Mts, along the tourist track No. 2, on rocks growing together with Lecanactis subdilleniana and Pertusaria sp. Lat.: 34 32' 22.93" N; Long.: 126 55' 11.16" E; Alt.: ca 495 m a.s.l. Coll.: Kon- 
dratyuk, S. (SK-82), Lőkös, L. (150357), 23.06.2015 (KoLRI 033952, sub Lecanactis subdilleniana); the same locality, growing together with Fuscidea oreana and Graphis cf koreana, (150359), (KoLRI 033954, sub Fuscidea coreana).

Lecanactis subdilleniana S. Y. Kondr., L. Lőkös et J.-S. Hur, spec. nova (Fig. 8)

Mycobank no.: MB 814523.

Similar to Lecanactis dilleniana, but differs in having less developed thallus, in having much smaller and very convex almost spherical apothecia, and in having longer ascospores, as well as in the lack of grey pruina on apothecium disc and the lack of $P D+$ yellow-orange reaction of thallus.

Type: South Korea: Jeollanam-do province, Jangheung-gun, Gwansaneup, Okdang-ri, Cheongwansan Mts, along the tourist track No. 2, on siliceous rock, growing together with Fuscidea sp. Lat.: $34^{\circ} 32^{\prime} 22.93^{\prime \prime} \mathrm{N}$; Long.: $126^{\circ}$ 55' 11.16" E; Alt.: ca 495 m a.s.l. Coll.: Kondratyuk, S. Y., Lőkös, L. (150362b), 23.06.2015 (holotype: KoLRI 033957); the same locality, growing together with Acarospora sp., Fuscidea sp. and Ramalina sp., (150363), (isotype: KoLRI 033958).

Thallus indistinct, can be rather numerous in places; usually very thin, the same thin as in peripheral portions (at the black line of thalline edge) as around the apothecia (i.e. not becoming thicker in the centre), and indistinctly verrucose in the centre or somewhat leprose appearance owing to numerous aerophytic algal cells overgrowing vertical rock surfaces; light greyish to whitish grey, whitish greenish or greyish-brownish; often can be distinguished only owing to scattered apothecia or can be seen owing to a well developed black line with crustose thalli of Fuscidea sp., with which very often associated.

Apothecia $0.4-0.8 \mathrm{~mm}$ diam., to $0.25-0.3 \mathrm{~mm}$ thick in section, scattered to somewhat grouped along the rock surface undulations or cracks, very indistinct, hardly seen in field and in the Lab conditions, from flat to very convex, almost spherical, from dull greyish brown to dull brown, dark brown or blackish, biatorine or lecideine, own margin from white or whitish grey at first, often with somewhat eroded margin (without pruina, but seem to be covered by mouldy fungi) to brown or whitish brown, greyish brown to indistinct (somewhat better seen when disc black); disc from plane at first to soon becoming very convex, being apothecia almost spherical, from grey or yellowish brown (but without pruina) to dark brown or blackish, often variegating coloration within the same thallus and within the same apothecium; in section lecideine or lecanorine, exciple entire, true exciple to 20-30 $\mu \mathrm{m}$ thick in the uppermost lateral and (40-)50-70 $\mu \mathrm{m}$ wide in lower lateral portion, 

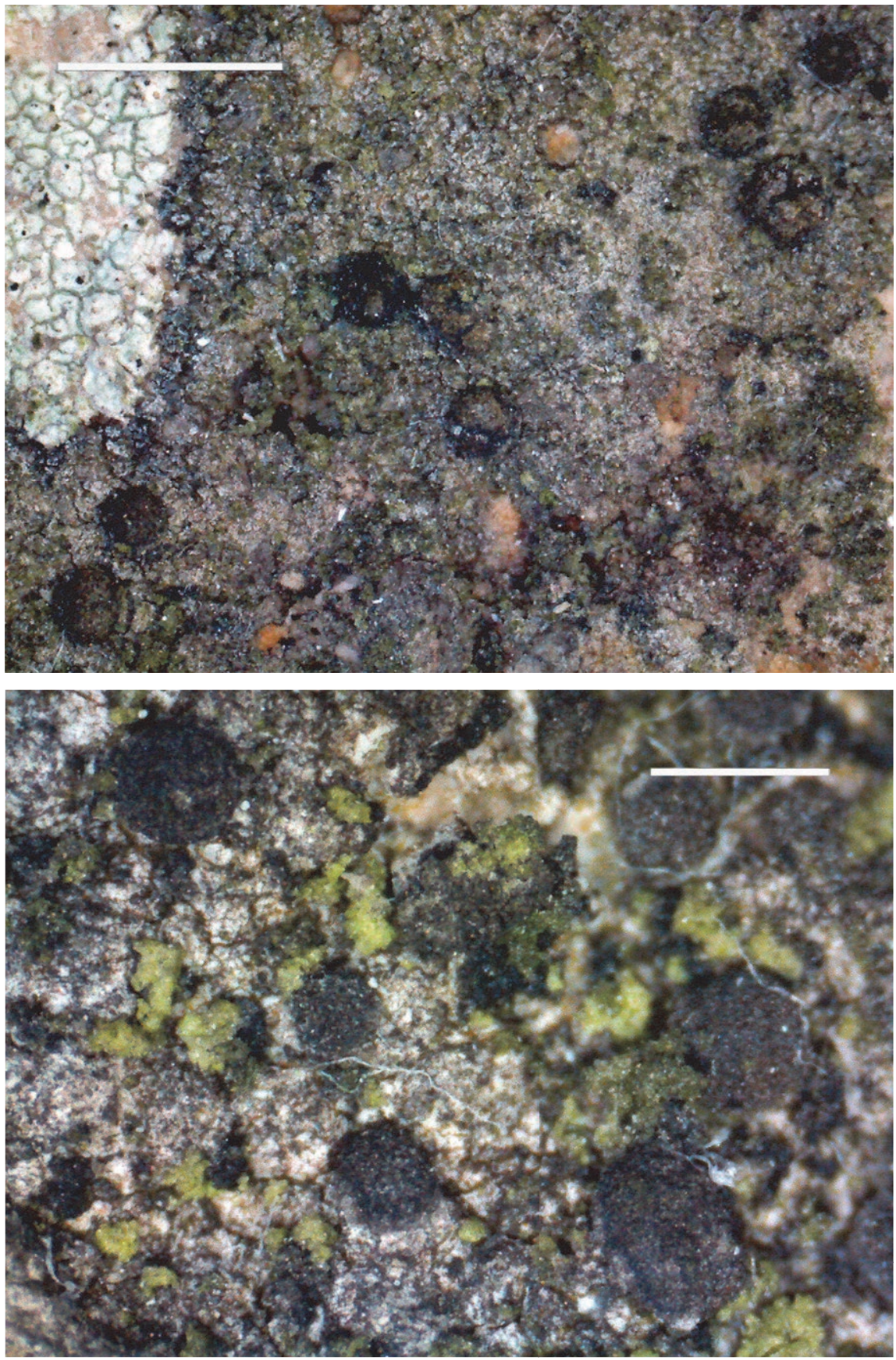

Fig. 8. Lecanactis subdilleniana, general habit (150363 - isotype). Scale $2 \mathrm{~mm}$ (top) and $1 \mathrm{~mm}$ (bottom) (photo: S. Kondratyuk) 
to (90-)100-120 $\mu \mathrm{m}$ thick in basal portion, black or brownish black; thalline exciple sometimes present, $60-90(-110) \mu \mathrm{m}$ thick with cortical layer to $15 \mu \mathrm{m}$ thick; hymenium 90-110 $\mu \mathrm{m}$ high; paraphyses almost not swollen towards the tips, to 2.5-3.5 $\mu \mathrm{m}$ diam., epihymenium in $\mathrm{K}$ becoming blackish olive; subhymenium to 30-40 $\mu \mathrm{m}$ thick, brownish, with oil droplets to 3-5 $\mu \mathrm{m}$ diam., $\mathrm{K}+$ greenish brown or greenish black; asci 8-spored, (85-)95-100 × 12-14 $\mu \mathrm{m}$; ascospores hyaline, (1-)3(-4)-septate, at overmature with distinct brownish grains, $(27-) 31-37(-41) \times 3.5-4.5(-5) \mu \mathrm{m}$.

Ecology: It grows on vertical rock surface, probably very often in places with periodically running water.

Etymology: Species epithet reflects similarity of this species to Lecanactis dilleniana.

Distribution: It is so far known from several localities in South Korea, Eastern Asia.

Taxonomic notes: Lecanactis subdilleniana is similar to rare European lichen L. dilleniana (Ach.) Körb., known from dry and shaded siliceous rock crevices and under overhangs, but differs in having less developed thallus ( $v$. thallus pale white-grey, tinged mauve or orange-pink (pale greyish in the herbarium), areolate to verrucose), in having much smaller and very convex almost spherical apothecia $(0.4-0.8 \mathrm{~mm} v$. $(0.3-) 0.5-1.5(-2) \mathrm{mm}$ diam., more or less plane, rounded, a few becoming angular and elongate apothecia), and in having longer ascospores ((27-)31-37(-41) × 3.5-4.5(-5) $\mu \mathrm{m} v \cdot(18-) 21-30(-33)$ $\times 4-5 \mu \mathrm{m}, 3(-5)$-septate), as well as in the lack of pruine (v. disc more or less exposed at maturity, grey-pruinose or rarely naked) and the lack of PD+ yellow-orange reaction of thallus and apothecium pruina as well as in the lack of psoromic, 2'-O-demethylpsoromic acid and schizopeltic acid (Egea and Torrente 1994).

Lecanactis subdilleniana is similar to rare Eastern Asian lichen Roccellina nipponica (Nyl.) Tehler, known from two localities of Japan, but differs in having much thinner and lighter thallus $(v .0 .4-0.8 \mathrm{~mm}$ thick, dark brown to dirty brown to brown-yellow), in having smaller apothecia (0.4-0.8 $\mathrm{mm} v .0 .5-1.9$ $\mathrm{mm}$ diam.), in having longer ascospores ((27-)31-37(-41) × 3.5-4.5(-5) $\mu \mathrm{m} v$. $24-29 \times 3-5 \mu \mathrm{m})$, as well as in the lack of a hypothecium extending down to the substrate, and in the lack of roccellic acid (Tehler 1983).

After having very spherical greyish-brownish apothecia Lecanactis subdilleniana can be similar to South Korean Rhopalospora sp. 1, but the latter differs in having hyaline epihymenium, in having Fuscidea / Teloschistes type of ascus, and in having much wider (or seem to be wider) ascospores owing to very attenuated both ends and almost rhomboid-shape of ascospores.

After variegating coloration of apothecium disc Lecanactis subdilleniana is similar to Ivanpisutia oxneri S. Y. Kondr., L. Lőkös et J.-S. Hur, recently described from Russian Far East and here recorded from South Korea as well, 
but differs in having another type of true exciple, in having another type of ascus and ascospores (Kondratyuk et al. 2015). The same great variation of colour of apothecia is recorded for Mikhtomia multicolor (Hue) S. Y. Kondr., Kärnefelt, A. Thell, Elix, J. Kim, A. S. Kondratiuk et J.-S. Hur, Yoshimuria spodoplaca (Nyl.) S. Y. Kondr., Kärnefelt, Elix, A. Thell, J. Kim, A. S. Kondratiuk et J.-S. Hur and some other Korean crustose lichens (Kondratyuk et al. 2013; Kondratyuk et al. 2014).

Additional specimen examined: South Korea. Jeju-do province: Jeju-si, Chuja-do Island, Chuja-myeon, Sinyang-1-ri, around grave of Hwangkyeonghan, on siliceous rock, growing together with Fuscidea, Porpidia and Ramalina spp. Lat.: $33^{\circ} 56^{\prime}$ 50.4" N; Long.: $126^{\circ} 20^{\prime} 21.05^{\prime \prime}$ E; Alt.: ca 116 m a.s.l. Coll.: Halda, J. P. (141010), 21.06.2014 (KoLRI 023566 sub Ramalina).

Specimens of Ivanpisutia oxneri examined: South Korea. Gangwon-do province: Hongcheon-gun, Nae-myeon, Eungboksan Mts, Tongbalam-gyegog, on bark. Lat.: $37^{\circ} 51^{\prime}$ 21.54" N; Long.: 128 30' 58.44" E; Alt.: ca 1,192 m a.s.l. Coll.: [sine nom.] (090671), 23.05.2009 (KoLRI 010338 sub Pertusaria amara); Jeongseong-gun, Gangneung-si, tourist pass toward peak Seokbyeongsan. Lat.: $37^{\circ} 34^{\prime} 38.58^{\prime \prime}$ N; Long.: $128^{\circ} 51^{\prime} 23.94^{\prime \prime}$ E; Alt.: ca $760 \mathrm{~m}$ a.s.l., on bark of Acer bourgeanum, A. truncatum var. barbinerve, Cornus controversus, and Tilia amurensis Coll.: Kondratyuk, S. (SK-91), Lőkös, L. (150932, 150933, 150934), 10.07.2015 (KoLRI 034165, KoLRI 034166, KoLRI 034167); the same place; Lat.: $37^{\circ} 34^{\prime} 41.82^{\prime \prime}$ N; Long.: $128^{\circ}$ 51' 37.65" E; Alt.: ca $810 \mathrm{~m}$ a.s.l., on bark of Acer bourgeanum, A. truncatum var. barbinerve, Cornus controversus, and Tilia amurensis. Coll.: Kondratyuk, S. (SK-92), Lőkös, L. (151000), 10.07.2015 (KoLRI 034233); the same place; Lat.: $37^{\circ} 34^{\prime} 36.55^{\prime \prime} \mathrm{N}$; Long.: $128^{\circ} 51^{\prime} 47.16^{\prime \prime} \mathrm{E}$; Alt.: ca 840 m a.s.l., on bark of Quercus mongolica, Q. serrata, and Tilia amurensis, Coll.: Kondratyuk, S. (SK-94), Lőkös, L. (151082, 151083), 10.07.2015 (KoLRI 034315, KoLRI 034316); the same place; Lat.: $37^{\circ} 34^{\prime} 46.37^{\prime \prime}$ N; Long.: $128^{\circ} 52^{\prime}$ 05.02" E; Alt.: ca $850 \mathrm{~m}$ a.s.l. on bark of Quercus mongolica, Quercus serrata, and Tilia amurensis, Coll.: Lőkös, L., Kondratyuk, S. (SK-96), 10.07.2015. 151167 (KoLRI 034400); Gangneung-si, Wangsan-myeon, Songhyeonri, Seokbyeongsan Mts, on Quercus bark. Lat.: 37 34' 29.9” N; Long.: $128^{\circ} 51^{\prime} 21.8^{\prime \prime}$ E; Alt.: ca 686 m a.s.l. Coll.: [sine nom.] (080191), 24.05.2008 (KoLRI 008437); Samcheok-si, Singimyeon, Macha-ri Gisdae-bong, on bark. Lat.: 37 18' 22.02" N; Long.: $128^{\circ} 56^{\prime} 45.96^{\prime \prime}$ E; Alt.: ca 1,222 m a.s.l. Coll.: [sine nom.] (090392), 15.05.2009 (KoLRI 010108 sub Ochrolechia trochophora). - Gyeongsangbuk-do province: Cheongsong-gun, Budong-myeon, Juwangsan Mts, on Carpinus bark. Lat.: 36² 24'09.6" N; Long.: 129 10’ 27.1" E; Alt.: ca 380 m a.s.l. Coll.: [sine nom.] (050742), 15.10.2005 (KoLRI 003646 sub Megalospora). - Gyeongsangnam-do province: Hadong-gun, Hwagae-myeon, Chirisan Mts (Byeoksoryeong-seseog). Lat.: $35^{\circ}$ 19' 40.74" N; Long.: $127^{\circ} 39^{\prime} 31.32^{\prime \prime}$ E; Alt.: ca. 1,346 m a.s.l., on bark, growing together with Biatora longispora, Coll.: [sine nom.] (091380), 15.10.2009 (KoLRI 011300 sub Ochrolechia sp. 1); Sancheong-gun, Sancheong-eup, along the tourist path to Ungseokbong. Lat.: $35^{\circ} 22^{\prime}$ 51.15" N; Long.: $127^{\circ} 52^{\prime} 32.56^{\prime \prime}$ E; Alt.: ca $270 \mathrm{~m}$ a.s.l. on bark, growing together with Biatora longispora, Coll.: Kondratyuk, S., Lőkös, L. (150218), 22.06.2015 (KoLRI 033813). Jeollanam-do province: Gurye-gun, Masan-myeon, Chirisan Mts, Hwaeom-gyegog, Lat.: $35^{\circ} 16^{\prime} 54.30^{\prime \prime} \mathrm{N}$; Long.: $127^{\circ} 31^{\prime} 0.18^{\prime \prime} \mathrm{E}$; Alt.: ca $816 \mathrm{~m}$ a.s.1., on bark, growing together with Lecidella sp., Coll.: [sine nom.] (091035), 12.10.2009 (KoLRI 010418 sub Lecidella). - New to Korea. 
Lecania chirisanensis S. Y. Kondr., L. Lőkös et J.-S. Hur, spec. nova (Fig. 9)

Mycobank no.: MB 814524.

Similar to Lecania rinodinoides, but differs in having larger apothecia, in having scleroplectenchymatous true exciple in lower lateral and basal portions, in having higher hymenium, in having thicker and inspersed with oil subhymenium, and in having longer and wider ascospores.

Type: South Korea: Gyeongsangnam-do province, Sancheong-gun, Sancheong-eup, along the tourist path to Ungseokbong. Lat.: $35^{\circ} 22^{\prime} 41.74^{\prime \prime}$ N; Long.: $127^{\circ} 52^{\prime}$ 21.93" E; Alt.: ca 324 m a.s.l. Coll.: Kondratyuk, S. (21574), Lőkös, L. (150260), 22.06.2015 (holotype: KoLRI 033855); from the same locality, (150261), (isotypes: KoLRI 033856, BP).

Thallus to $3-4 \mathrm{~cm}$ across, but may form larger aggregation, crustose, continuous, very thin, film-like, repeating all undulations or shape of rock crystals, often exfoliated and hollows between substrate and thallus-film observed, greenish grey to light greyish, with very numerous and usually rather large biatorine apothecia. Hypothallus absent, while dark grey or blackish edge to $0.3-0.5 \mathrm{~mm}$ wide in contact with other crustose lichens observed.

Apothecia $0.3-1.1 \mathrm{~mm}$ diam., (in section to $0.3 \mathrm{~mm}$ thick), seem to be biatorine, but lecanorine or zeorine in the section, rather numerous, scattered, mainly regularly rounded, at first with plane dull brownish to dull dark brown disc and dull yellowish or dull whitish to dull yellowish brown own margin, but soon becoming semi-convex, dark brown or dull brown with hardly distinct own margin, concolorous with disc; in section lecanorine of zeorine, thalline margin to $70-80 \mu \mathrm{m}$ thick with cortical layer from $10 \mu \mathrm{m}$ thick of textura intricata to 30-40 $\mu \mathrm{m}$ thick, mesodermatous paraplectenchymatous; true exciple (30-)40-80 $\mu \mathrm{m}$ thick in uppermost and 60-70 $\mu \mathrm{m}$ thick in lower lateral portions, (20-)25-70 $\mu \mathrm{m}$ thick in basal portions, scleroplectenchymatous with well-developed matrix and hyphae lumina 1-1.5 $\mu \mathrm{m}$ diam.; hymenium 80-90 $\mu \mathrm{m}$ high; paraphyses to $3.5-4 \mu \mathrm{m}$ diam. towards the tips (indistinct in both water and $\mathrm{K}$ ); subhymenium $60-70 \mu \mathrm{m}$ thick, inspersed with oil droplets to 3-5(-7) $\mu \mathrm{m}$ diam. (better seen in K), hyaline; asci 8-spored; ascospores 1-septate, hyaline, elongated ellipsoid to somewhat clavate, where one cell is wider of other, larger cells often almost spherical, with distinct constriction at the septum, often with some remnants from ascus cavity which can be accepted as a halo, to $1 \mu \mathrm{m}$ thick, (15-)17-22(-25) × (6-)7-10(-11) $\mu \mathrm{m}$.

Ecology: On siliceous rocks at low altitudes in mixed forest zone (with oak and Pinus trees) of mountains. 

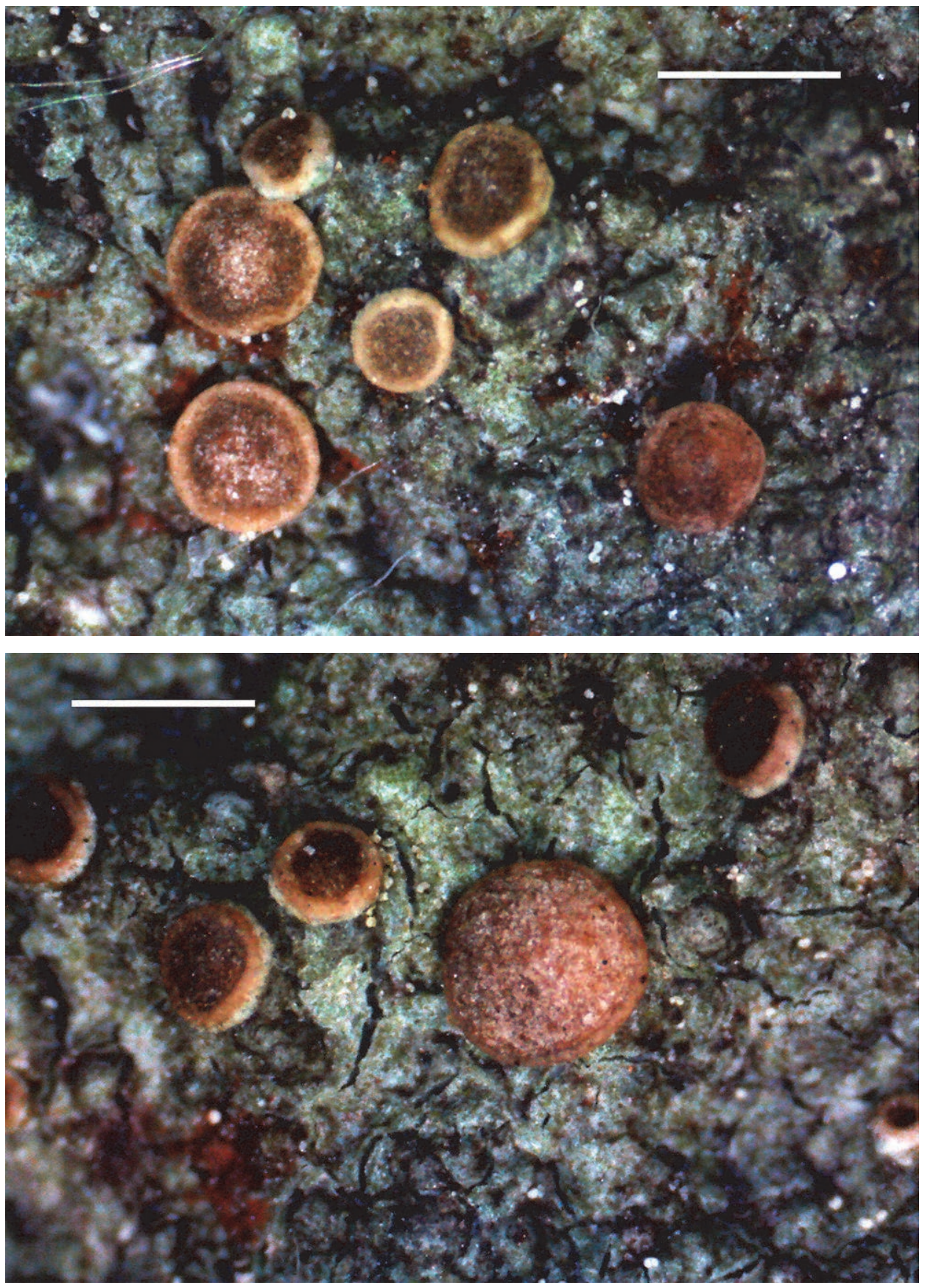

Fig. 9. Lecania chirisanensis, general habit (holotype). Scale $1 \mathrm{~mm}$ (photo: S. Kondratyuk) 
Distribution: So far it is known only from the type locality in the Chiri Mts of South Korea, Eastern Asia.

Etymology: It is named after Chiri Mts (in Korean 'Chiri-san') where type collection was done.

Taxonomic notes: Lecania chirisanensis is similar to Lecania rinodinoides $\mathrm{S}$. Y. Kondr., L. Lőkös et J.-S. Hur, but differs in having larger apothecia (0.3-1.1 v. $0.2-0.5 \mathrm{~mm}$ diam.), in having scleroplectenchymatous true exciple in lower lateral and basal portions ( $v$. paraplectenchymatous), in having higher hymenium (80-90 $\mu \mathrm{m} v \cdot 60-70 \mu \mathrm{m}$ high), in having thicker and inspersed with oil subhymenium $(60-70 \mu \mathrm{m} v .30-40 \mu \mathrm{m}$ thick), and in having longer and wider ascospores $((15-) 17-22(-25) \times(6-) 7-10(-11) \mu \mathrm{m} v \cdot(11-) 13-18(-19) \times(4.5-) 5-6$ $(-7) \mu \mathrm{m})$ (see also Kondratyuk et al. 2013).

Lecania chirisanensis can be keyed to Halecania tornensis (H. Magn.) M. Mayrhofer, known from North Europe (Sweden), but differs in having thin film-like, greenish grey thallus ( $v$. thick to bullate with deep cracks between thalline portions, middle or dark brown with white cracks), in having larger and dull brown apothecia (0.3-1.1 v. to $0.6 \mathrm{~mm}$ diam., black), in having inspersed with oil subhymenium $(v$. hymenium inspersed with oil, not subhymenium), in having slightly widened paraphyses towards the tips $(3-4 \mu \mathrm{m} v$. $6-7(-8) \mu \mathrm{m}$ wide) and lacking dark cups at their tips, in having Bacidia-type (v. Catillaria-type) of ascus and in having longer ascospores $(17-22 \times 7-10 \mu \mathrm{m}$ v. 15-20 × (7-)8-11(-7) $\mu \mathrm{m})$, as well as in the lack of pruine on thallus, in the lack of ascospore halo.

Lecania chirisanensis can be keyed to Halecania alpivaga (Th. Fr.) M. Mayr_ hofer, known from Europe (from Greece to Arctic regions), but differs in having paraphyses lacking dark cups at their tips, in having inspersed with oil subhymenium (no oil in the apothecium section), in having Bacidia-type (v. Catillaria-type) of ascus and in having longer and wider ascospores (17-22 $\times$ 7-10 $\mu \mathrm{m} v$. 13.5-17.5 $(-22) \times 5.5-7 \mu \mathrm{m})$, as well as in the lack ascospore halo.

At first look Lecania chirisanensis may resemble Biatora or Bacidia species with greenish grey thallus and dark brown biatorine apothecia. However, microscopically these taxa are very different and can be easily identified.

Maronella coreana S. Y. Kondr., L. Lőkös et J.-S. Hur, spec. nova (Fig. 10)

Mycobank no.: MB 814525.

Similar to Maronella laricina, but differs in having much thinner often epiphloed thallus, in having biatorine apothecia, in having well-developed true exciple, in having smaller amount of ascospores in the ascus, and in having larger ascospores, as well as in the lack of thalline exciple. 
Type: South Korea: Gangwon-do province, Taebaek-si, Sodo-dong, Mt Taebaek, on bark, growing together with Lecanora imshaugii, Lecidella elaeochroma, Lecidella sp. and Rinodina sp. Lat.: $37^{\circ} 06^{\prime} 39.1^{\prime \prime} \mathrm{N}$; Long.: $128^{\circ} 55^{\prime} 41.2^{\prime \prime}$ E; Alt.: ca 935 m a.s.l. Coll.: Hur, J.-S. (040078), 27.02.2004 (holotype: KoLRI 000842 sub Lecanora imshaugii).

Thallus to $1 \mathrm{~cm}$ across, crustose, mainly endophloed and indistinct, but some places with indistinct areoles to $0.2-0.3 \mathrm{~mm}$ across, whitish or whitishgreyish to yellowish white, usually with apothecium or around apothecia seen. Hypothallus not seen.

Apothecia 0.3-0.4(-0.5) $\mathrm{mm}$ diam./across, in section apothecium to 0.2$0.25 \mathrm{~mm}$ thick, indistinctly biatorine, at first plane or slightly convex, with well-developed and well-seen (at $\times 100$ and more) transparent or dull hyaline or dull yellowish true exciple (own margin) and somewhat darker to blackish greyish plane or slightly convex disc, but soon becoming convex with very rough surface and very variegated colouration within the same apothecium, from transparent or dull whitish-greyish in places to blackish transparent or brownish transparent in the same apothecium; in section true exciple to 30-35 $\mu \mathrm{m}$ thick in the uppermost and lower lateral portions and to 20-30 $\mu \mathrm{m}$ thick of strongly agglutinated hyphae or matrix with hypha lumina to $2-3 \mu \mathrm{m}$ diam., transparent or lightly yellowish-brownish; hymenium to $80 \mu \mathrm{m}$ high, hyaline, epihymenium somewhat greenish-bluish-blackish in places, becoming greenish blackish in $\mathrm{K}$, paraphyses to $1.5 \mu \mathrm{m}$ diam. in lower portion and slightly swollen towards the tips, to $3 \mu \mathrm{m}$ diam.; asci of Maronella-type of ascus (sensu Hafellner 1995), broadly clavate, with about 100 or more ascospores, 40-45× 18-20(-25) $\mu \mathrm{m}$; ascospores simple, hyaline, elongated to bacilliform, rarely somewhat ellipsoid or slightly curved, $(4-) 5-6.5(-7) \times(1.5-) 1.8-2.2(-2.5) \mu \mathrm{m}$. Conidiomata and conidia not seen.

Chemistry: Thallus and apothecium $\mathrm{K}-$, section of apothecium becoming slightly lighter (especially in its lower part) in K, while epithecium becoming intensively greenish-blackish in places.

Ecology: It grows on bark of deciduous tree.

Etymology: It is named after country of type collection, i.e. South Korea.

Distribution: So far known only from type collection, from South Korea, Eastern Asia.

Taxonomic notes: Maronella coreana is similar to M. laricina M. Steiner, but differs in having much thinner often epiphloed thallus, in having biatorine $(v$. lecanorine) apothecia, in having well developed true exciple, in having smaller amount of ascospores in the ascus (about $100 v .200$ and more) and in having larger (longer and wider) ascospores ((4-)5-6.5(-7) × (1.5-)1.8-2.2(-2.5) $\mu \mathrm{m} v .3-4 \times 1.5 \mu \mathrm{m})$, as well as in the lack of thalline exciple (Hafellner 2004, Steiner 1959). 

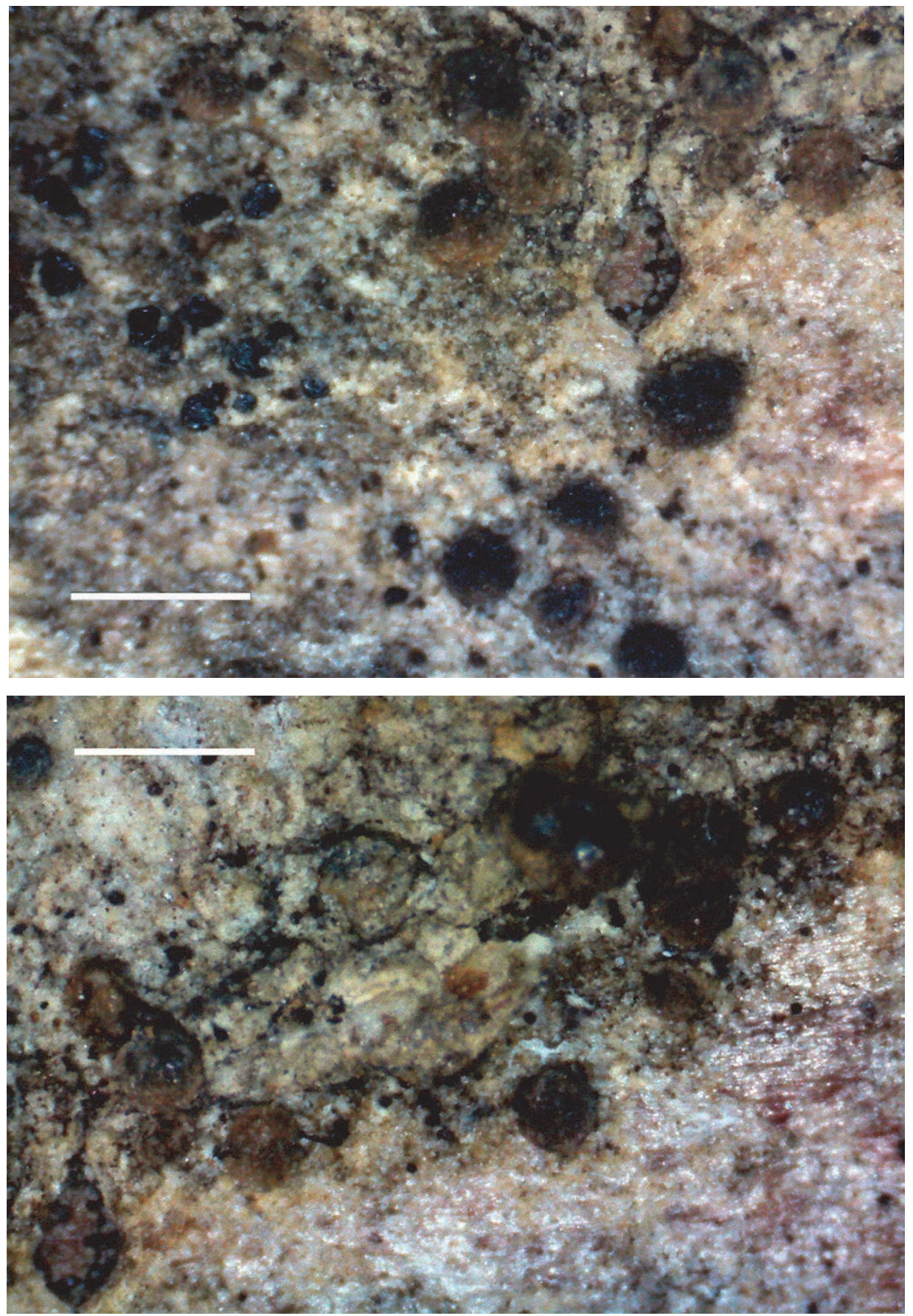

Fig. 10. Maronella coreana, general habit (holotype). Scale $1 \mathrm{~mm}$ (photo: S. Kondratyuk) 
After having bacilliform ascospores and polyspored asci Maronella coreana is similar to Maronina australiensis Hafellner et R. W. Rogers, an endemic species of Australian Queensland, but differs in having much smaller apothecia (0.3-0.4(-0.5) $\mathrm{mm} v$. 0.5-1.5(-2.0) $\mathrm{mm}$ diam.), in the having Maronella-type of ascus (sensu Hafellner 1995) (v. Lecanora-type of ascus), in having much larger amount of ascospores in the ascus (about 100 or more $v$. 16-32 per ascus), and in having smaller ascospores $((4-) 5-6.5(-7) \times(1.5-) 1.8-2.2(-2.5) \mu \mathrm{m} v .9-12(-14)$ $\times 2-3(-3.5) \mu \mathrm{m})$, as well as in the lack of thick, persistent and corticated thalline margin, and in the lack of reddish brown disc of apothecia (McCarthy 2004).

After having bacilliform ascospores and polispored asci Maronella coreana can be keyed as the member of the genus Sarcosagium. However, it differs from S. campestre (Fr.) Poetsch et Schied., inconspicuous, ephemeral species, known from more or less base-rich or acidic soils and decaying mosses of Europe and North America, in having another colour of apothecium (pale yellowish or pinkish brown or pallid translucent when wet), in having lower hymenium (to $80 \mu \mathrm{m} v .120-170 \mu \mathrm{m}$ high), in having Maronella-type of ascus (v. asci cylindrical and lacking an apical dome), in having smaller ascospores $((4-) 5-6.5(-7) \times(1.5-) 1.8-2.2(-2.5) \mu \mathrm{m} v .5-8 \times 2-2.3 \mu \mathrm{m})$ (Gilbert 2004).

Melanophloea coreana S. Y. Kondr., L. Lőkös et J.-S. Hur, spec. nova (Fig. 11)

Mycobank no.: MB 814526.

Similar to Melanophloea americana, but differs in having one hymenium, in having dark dull brown or dark brown apex in the centre of ascoma, in having much wider ascospores.

Type: South Korea: Gangwon-do province, Samcheok-si, Wondeok-eup, Sinnam-gil, seashore rocks, on siliceous rock, growing together with Acarospora, Catillaria, Lecania, Lichenothelia and Ramalina spp. Lat.: $37^{\circ} 15^{\prime} 34.68^{\prime \prime} \mathrm{N}$; Long.: $129^{\circ} 20^{\prime} 03.56^{\prime \prime}$ E; Alt.: ca 5 m a.s.l. Coll.: Lőkös, L. (LL-101), Kondratyuk, S. (151353), 11.07.2015 (holotype: KoLRI 034586).

Thallus usually indistinct, consisting of scattered thalline verruculae (with immersed ascomata or conidiomata), very dispersed and scattered, usually single and very rarely aggregated/closely sitting together along the rock cracks or undulations, medium brown to dark brown or blackish brown (at higher magnification with medium brown to dark brown flattened portion in the centre of verruculae and blackish sides), (0.2-)0.3-0.5 mm across, upper surface of thalline warts sometimes shiny, smooth and often with cracks, as well as often with Trentepohlia cell groups (in sections). Hypothallus not observed. 

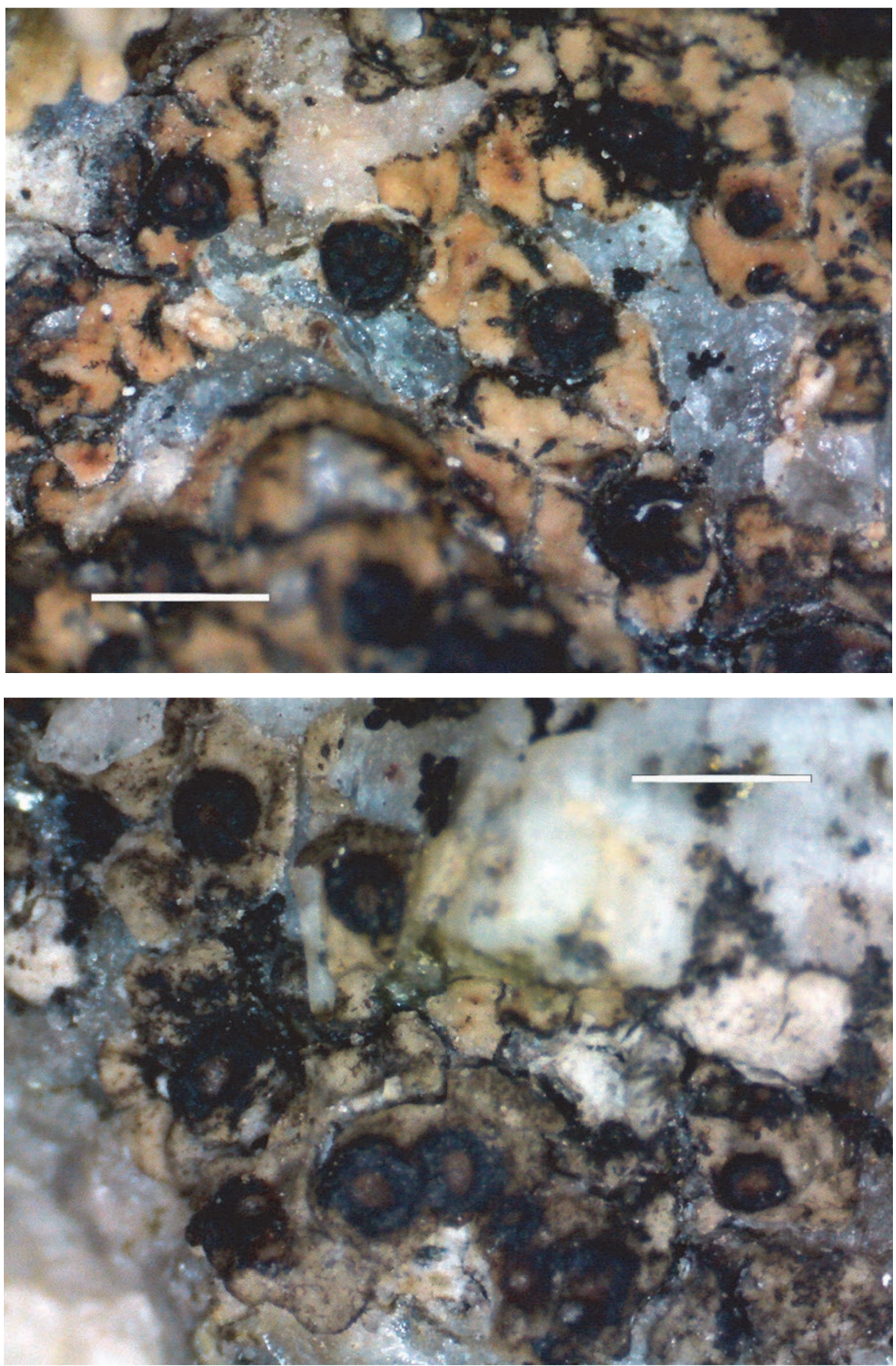

Fig. 11. Melanophloea coreana, general habit (110323). Scale $1 \mathrm{~mm}$ (photo: S. Kondratyuk) 
Ascomata apothecioid to 0.3-0.5(-0.6) $\mathrm{mm}$ diam., in section $0.3 \mathrm{~mm}$ thick, immersed in thalline warts, dark brown to black brown, with distinct flat dull brown centre of ascoma to (40-)60-100(-120) $\mu \mathrm{m}$ wide; in section wall of ascomata three layered, outer thalline wall with blackish outermost layer of cortex, inner hyaline with compact hyphae and medium layer hyaline with algal cells and somewhat hollow medulla; thalline cortex to (50-)70-80 $\mu \mathrm{m}$ thick in the uppermost portion at the ostiole, outer layer medium brown to blackish brown to 10-15 $\mu \mathrm{m}$ thick, while inner hyaline, becoming slightly thinner to $40-50(-70) \mu \mathrm{m}$ thick at sides and to $40-80(-100) \mu \mathrm{m}$ thick in lower lateral portion, outer portion to 15-20(-30) $\mu \mathrm{m}$ thick, inner hyaline; the inner wall of nucleus (an incurving exciple) to 10-15 $\mu \mathrm{m}$ thick; algal cells only in the inner portion of thalline wall at the basis, as separate groups of cells, cells to 15(-18) $\mu \mathrm{m}$ diam., much rarely as algal zone to $30-50 \mu \mathrm{m}$ thick between the thalline cortex and the inner wall of nucleus; hymenium to $190 \mu \mathrm{m}$ high; paraphyses to $1-1.2 \mu \mathrm{m}$ diam., not swollen at the apices, branched; subhymenium to 40 $\mu \mathrm{m}$ thick, hyaline sometimes with oil droplets; asci polyspored, with more of 200 ascospores, $120-150 \times 17-30 \mu \mathrm{m}$, with distinctly swollen tips, ascospores simple, hyaline, elongated, $3-5(-6) \times 1.5-2.2(2.5) \mu \mathrm{m}$. Conidiomata immersed into thalline warts the same as ascomata, $0.2-0.4 \mathrm{~mm}$ across (to $0.35 \mathrm{~mm}$ diam. in section); conidia narrowly bacilliform, 5-6 $60.7-0.8 \mu \mathrm{m}$.

Ecology: It grows on siliceous rocks at low altitudes of mountain region.

Etymology: It is named after Korea, where type collection was done.

Distribution: It is known so far from several localities of Cheongwansan Mts, South Korea, Eastern Asia.

Taxonomic notes: Melanophloea coreana is similar to M. americana K. Knudsen et Lendemer, known from siliceous rocks in riparian areas of North America (USA: Pennsylvania and New York), but differs in having one hymenium (v. ascomata compound with two-four hymenia separated by exciple layer and with 2-4 openings, not centered at apex of ascomata), in having dark dull brown or dark brown apex in the centre of ascoma $(v$. hyaline or pale yellowish), in having much wider ascospores (3-5(-6) × 1.5-2.2(2.5) $\mu \mathrm{m} v .3-5 \times 0.5-1$ $\mu \mathrm{m})$ (Knudsen and Kocourkova 2013, Knudsen et al. 2011).

Unfortunately data on conidia of $M$. americana are hitherto missing and we cannot carry out comparison of these data for two species mentioned. Specimen 150375 was presented only by conidiomata, while the other specimens have ascomata.

Additional specimens examined: Republic of Korea. Gyeongsangbuk-do province: Uljin-gun, Giseong-myeon, Mangyang 1-gil, on granitic seashore rocks, growing together with Caloplaca multicolor, Catillaria, Lecania and Lecidella spp. Lat.: 36 50' 05.29" N; Long.: $129^{\circ} 26^{\prime}$ 35.54" E; Alt.: ca 5 m a.s.l. Coll.: Kondratyuk, S. (SK-103), Lőkös, L. (151428), 12.07.2015 (KoLRI 034661). - Gyeongsangnam-do province: Sancheong-gun, Sancheongeup, along the tourist path to Ungseokbong. Lat.: $35^{\circ} 22^{\prime} 37.25^{\prime \prime} \mathrm{N}$; Long.: $127^{\circ} 52^{\prime} 16.37^{\prime \prime}$ 
E; Alt.: ca 382 m a.s.l. Coll.: Kondratyuk, S. (21575), Lőkös, L. (150269), 22.06.2015 (KoLRI 033864). - Jeollanam-do province: Hampeong county, Dolmeoli beach. Lat.: $35^{\circ} 05.134^{\prime}$ N; Long.: $126^{\circ} 26.158^{\prime}$ E; Alt.: ca 3 m a.s.l. Coll.: Wang. X. Y., Ryu, J. A. (110323) 01.06.2011 (KoLRI 012909 sub Buellia cf spuria); Jangheung-gun, Gwansan-eup, Okdang-ri, Cheongwansan Mts, along the tourist track No. 2, on rock, growing together with Acarospora sp. and Stereocaulon spp. Lat.: 34 32' 22.93" N; Long.: 126 55' 11.16" E; Alt.: ca 495 m a.s.l. Coll.: Kondratyuk, S. (21582), Lőkös, L. (150374), 23.06.2015 (KoLRI 033969); the same locality, (150375), (KoLRI 033970); the same locality, (150376), (KoLRI 033971).

Acknowledgements - This work was supported by the Korea National Research Resource Center Program, the Korean Forest Service Program (KNA 2012) through the Korea National Arboretum, and (for FE and LL) the Hungarian Scientific Research Fund (OTKA K81232).

\section{REFERENCES}

Aptroot, A. and Moon, K. H. (2014): 114 new reports of microlichens from Korea, including the description of five new species, show that the microlichen flora is predominantly Eurasian. - Herzogia 27(2): 347-365. http://dx.doi.org/10.13158/heia.27.2.2014.347

Aptroot, A. and Moon, K. H. (2015): New lichen records from Korea, with the description of the lichenicolous Halecania parasitica. - Herzogia 28(1): 193-203. http://dx.doi. org/10.13158/heia.28.1.2015.193

Arvidsson, L. (1982): A monograph of the lichen genus Coccocarpia. - Opera Bot. 67: 1-96.

Degelius, G. (1974): The lichen genus Collema with special reference to the extra-European species. - Symb. Bot. Upsal. 20: 1-215.

Egea, J. M. and Torrente, P. (1994): El género de hongos liquenizados Lecanactis (Ascomycotina). - Biblioth. Lichenol. 54: 1-205.

Etayo, J. and Marbach, B. (2003): Hafellia alisioae and H. gomerana (lichenized Ascomycetes, Physciaceae), two new species from the Canary Islands, with a key to all known corticolous species. - Lichenologist 35(5-6): 369-375. http://dx.doi.org/10.1016/S00242829(03)00054-9

Fletcher, A. and Coppins, B. J. (2009): Halecania M. Mayrhofer (1987). - In: Smith, C. W., Aptroot, A., Coppins, B. J., Fletcher, A., Gilbert, O. L., James, P. W. and Wolseley, P. A. (eds): The lichens of Great Britain and Ireland. The British Lichen Society, London, pp. $426-428$.

Gilbert, O. L. (2004): The phenology of Sarcosagium campestre observed over three years. - Lichenologist 36(2): 159-161. http://dx.doi.org/10.1017/S0024282904014021

Giralt, M., Tønsberg, T. and Holien, H. (2002): Notes on the misunderstood Buellia dives (Th. Fr.) Th. Fr. - Lichenologist 34(1): 1-5. http://dx.doi.org/10.1006/lich.2001.0363

Hafellner, J. (1995): Towards a better circumscription of the Acarosporaceae (lichenized Ascomycotina, Lecanorales). - Crypt. Bot. 5(2): 99-104.

Hafellner, J. (2004): A revision of Maronella laricina and Piccolia ochrophora. - Symb. Bot. Upsal. 34(1): 87-96.

Harada, H., Okamoto, T. and Yoshimura, I. (2004): A checklist of lichens and lichen-allies of Japan. - Lichenology 2(2): 47-165.

Hur, J.-S., Koh, Y. J. and Harada, H. (2005): A checklist of Korean lichens. - Lichenology 4(2): 65-95. 
Inoue, M. (1981): A taxonomic study of the Japanese species of Fuscidea (lichens). - Hikobia, Suppl. 1: 161-176.

Kantvilas, G. (2004a): Fuscidea. - In: McCarthy, P. M. and Mallett, K. (eds): Flora of Australia. Volume 56A, Lichens 4. ABRS/CSIRO Australia, Melbourne, pp. 174-182.

Kantvilas, G. (2004b): Fuscideaceae. - In: McCarthy, P. M. and Mallett, K. (eds): Flora of Australia. Volume 56A, Lichens 4. ABRS/CSIRO Australia, Melbourne, pp. 173-174.

Knudsen, K. and Kocourkova, J. (2013): Lichenological notes 6: nomenclatural acts. - Mycotaxon 124: 353-359. http://dx.doi.org/10.5248/124.353

Knudsen, K., Lendemer, J. C. and Harris, R. C. (2011): Studies in lichens and lichenicolous fungi, no. 15: miscellaneous notes on species from eastern North America. - Opusc. Philolich. 9: 45-75.

Kondratyuk, S. Y., Lőkös, L., Tschabanenko, S., Haji Moniri, M., Farkas, E., Wang, X. Y., Oh, S.-O. and Hur, J.-S. (2013): New and noteworthy lichen-forming and lichenicolous fungi. - Acta Bot. Hung. 55(3-4): 275-349. http://dx.doi.org/10.1556/ABot.55.2013.3-4.9

Kondratyuk, S. Y., Kärnefelt, I., Thell, A., Elix, J. A., Kim, J., Jeong, M. H., Yu, N. H., Kondratiuk, A. S. and Hur, J.-S. (2014): A revised taxonomy for the subfamily Xanthorioideae (Teloschistaceae, Ascomycota) based on molecular phylogeny. - Acta Bot. Hung. 56(1-2): 141-178. http://dx.doi.org/10.1556/ABot.56.2014.1-2.12

Kondratyuk, S. Y., Lőkös, L., Farkas, E., Oh, S.-O. and Hur, J.-S. (2015): New and noteworthy lichen-forming and lichenicolous fungi 2. - Acta Bot. Hung. 57(1-2): 77-141. http:// dx.doi.org/10.1556/ABot.57.2015.1-2.10

Kurokawa, S. (ed.) (2003): Checklist of Japanese lichens. - National Science Museum, Tokyo, $128 \mathrm{pp}$.

Marbach, B. (2000): Corticole und lignicole Arten der Flechtengattung Buellia sensu lato in den Subtropen und Tropen. - Biblioth. Lichenol. 74: 1-384.

Mayrhofer, M. (1987): Studien über die saxicolen Arten der Flechtengattung Lecania in Europa I. Halecania gen. nov. - Herzogia 7: 381-406.

McCarthy, P. M. (2004): Maronina. - In: McCarthy, P. M. and Mallett, K. (eds): Flora of Australia. Volume 56A, Lichens 4. ABRS/CSIRO Australia, Melbourne, pp. 62-63.

Moon, K. H. (2013): Lichen-forming and lichenicolous fungi of Korea. - National Institute of Biological Resources, Korea, 139 pp.

Räsänen, V. (1940): Lichenes ab A. Yasuda et aliis in Japonia collecti (I), (II). - J. Jap. Bot. 16: 82-98, 139-153.

Ri, J. D. (1988): Spore plants of Korea. 7. Lichens. - Pyongyang. [In Korean]

Sheard, J. W. (1992): The lichenized ascomycete genus Hafellia in North America. - Bryologist 95(1): 79-87. http://dx.doi.org/10.2307/3243788

Sheard, J. W. and May, P. F. (1997): A synopsis of the species of Amandinea (lichenized Ascomycetes, Physciaceae) as presently known in North America. - Bryologist 100(2): 159-169. http://dx.doi.org/10.2307/3244044

Steiner, M. (1959): Maronella laricina n. gen., n. spec. (Acarosporaceae), eine neue Flechte aus Tirol. - Österr. Bot. Zeitschr. 106(5): 440-455. http://dx.doi.org/10.1007/bf01289322

Szerdahelyi, T. and Lőkös, L. (1992): Botanical collectings by the Hungarian Natural History Museum in Korea. A report on the collectings of the 2nd expedition. - Studia bot. hung. 23: 127-133.

Tehler, A. (1983): The genera Dirina and Roccellina. - Opera Bot. 70: 1-86.

Vězda, A. (1988): Lichenes selecti exsiccati. Fasc. XCI. 2251-2275. (nos. 2253, 2256, 2259, 2264). - Brno, pp. 1-8. 